\title{
Piętnaście lat digitalizacji w Archiwum Państwowym w Lublinie*
}

Abstrakt: Archiwum Państwowe w Lublinie od 2002 r. digitalizuje archiwalia i jest jednym z pionierów w tym zakresie wśród archiwów państwowych. Lubelskie Archiwum nieustannie kontroluje proces digitalizacji w celu przystosowania go do rosnących wymogów społeczeństwa informacyjnego oraz realizacji misji trwałego zachowania świadectw przeszłości i zapewnienia do nich powszechnego dostępu w ramach wspierania rozwoju państwa i społeczeństwa obywatelskiego. Doświadczenie, które Archiwum zdobyło podczas 15 lat digitalizacji swego zasobu, jest wynikiem dobrze określonych zasad na szczeblu Naczelnej Dyrekcji i konsekwentnej ich realizacji przez dyrekcję i pracowników Archiwum. Realizując cele digitalizacji archiwaliów, lubelskie Archiwum może się szczycić pokaźnym wkładem w cyfrowe zabezpieczanie i udostępnianie zasobu archiwalnego.

sŁowA KLUCzowe: digitalizacja, zabezpieczanie, udostępnianie, kopia cyfrowa, skaner.

* Artykuł powstał na podstawie pracy dyplomowej Michała Zawady Digitalizacja materiałów archiwalnych w Archiwum Państwowym w Lublinie, napisanej pod kierunkiem prof. dr. hab. Krzysztofa Skupieńskiego, w Zakładzie Archiwistyki i Nauk Pomocniczych Historii Uniwersytetu Marii Curie-Skłodowskiej w Lublinie w 2015 r. Tekst pracy dyplomowej uzupełniono o rys historyczny poświęcony digitalizacji w Archiwum Państwowym w Lublinie w latach 2002-2017, autorstwa Michała Zawady i Marka Krzykały, oraz o część statystyczną dotyczącą wyników digitalizacji w lubelskim Archiwum w latach 2002-2016. 
U schyłku drugiej dekady XXI w. nikt już chyba nie wątpi, że digitalizacja materiałów archiwalnych, stanowiących zasób archiwów państwowych, jest tą częścią działalności archiwalnej, od której ani nie ma ucieczki, ani nie jest ona wskazana. Wymogi rozwoju społeczeństwa informacyjnego oraz rola, jaką spełniają w nim ogólnodostępne zasoby cyfrowe, uświadomiły archiwom państwowym, z jednej strony, konieczność udzielenia szerszego dostępu do archiwaliów, z drugiej, szansę na ich zaistnienie w świadomości obywateli jako ważnych instytucji pamięci narodu i państwa. Co więcej, „szeroko rozumiany ustawowy obowiązek udostępniania informacji, zawartych w zasobie archiwalnym, jest bezsprzecznie najlepiej kojarzony i utożsamiany w odbiorze społecznym z pierwszoplanowymi zadaniami archiwów państwowych"1. Można nawet pójść o krok dalej i stwierdzić, że „istnienie archiwów ma sens wówczas, gdy gromadzone w archiwach materiały służyć mają człowiekowi - użytkownikowi”2. Digitalizacja materiałów archiwalnych ma w swych założeniach sprostać potrzebom informacyjnym społeczeństwa oraz „podnieść w odbiorze społecznym rolę i znaczenie archiwów państwowych”. Archiwum Państwowe w Lublinie już w 2002 r. dostrzegło, jak wielkie znaczenie ma digitalizacja materiałów archiwalnych, i podjęło pierwsze próby stworzenia ich kopii cyfrowych. Biorąc pod uwagę ówczesne możliwości finansowe oraz parametry sprzętowe skanerów, należy przyznać, że wytworzone wtedy kopie cyfrowe nie prezentują tej jakości, jaką mają kopie powstałe w latach późniejszych. Tym, co nie straciło jednak na swej jakości, jest doświadczenie lubelskiego Archiwum w prowadzeniu digitalizacji archiwaliów, zarówno od strony sprzętowej i kadrowej, jak również proceduralnej i merytorycznej. Rozwijając w kolejnych latach, zwłaszcza od 2007 r., własną pracownię digitalizacji, zaś w latach 2012-2014 pracownie w oddziałach zamiejscowych w Chełmie, Kraśniku i Radzyniu Podlaskim, Archiwum Państwowe w Lublinie wypracowało taką organizację procesu digitalizacji, która pozwala na sprawne i efektywne jej prowadzenie.

${ }^{1}$ Załącznik do Komunikatu nr 1/2010 Naczelnego Dyrektora Archiwów Państwowych (dalej NDAP) z 23 XII 2010 r., Strategia archiwów państwowych na lata 2010-2020 (dalej Strategia), s. 4.

${ }^{2}$ M. Jędralska, Automatyzacja $w$ bibliotekach, automatyzacja $w$ archiwach - czy te drugie zdąża ze zmianą?, „Archiwista Polski” T. 4, 2012, s. 31.

${ }^{3}$ Strategia, s. 4. 


\section{Rys historyczny}

Jako datę rozpoczęcia digitalizacji w Archiwum Państwowym w Lublinie przyjmuje się październik 2002 r., kiedy to Archiwum zakupiło skaner książkowy Minolta PS70oo ze środków przyznanych przez Państwowy Fundusz Rehabilitacji Osób Niepełnosprawnych oraz, w ramach tego Funduszu, utworzyło stanowisko pracy związane z digitalizacją zasobu. Wcześniej Archiwum posiadało jedynie skaner płaski formatu A4 firmy Plustek, jednakże zakres, w jakim był on wykorzystywany, nie upoważnia do nazwania tego digitalizacją zasobu. Rzadko i sporadycznie wykorzystywany był w realizacji zamówień z pracowni naukowej, wykonano także kilka skanów do celów prezentacji zasobu w Internecie.

Skaner Minolta PS70oo to skaner książkowy pracujący w sposób bezdotykowy. Oznacza to, że podczas skanowania nie ma bezpośredniego, fizycznego kontaktu z szybą szklaną i nie ma potrzeby dociskania do niej skanowanego materiału. Zakres przestrzeni kolorów obejmuje jednakże tylko 8-bitową skalę szarości oraz tryb bitonalny, czyli czarno-biały. Ze względu jednak na brak szyby dociskowej wydawał się doskonały do wykorzystania w archiwach. Na rynku można było ówcześnie znaleźć kilka modeli skanerów książkowych, które były przedstawiane przez producentów jako idealne do pracy w archiwum - wśród nich także kolorowe - jednakże wszystkie one posiadały w swoim stałym wyposażeniu szybę dociskową, która po przeprowadzeniu testów wykazała niestety tendencje do niszczenia archiwaliów, najczęściej poprzez zgniatanie i łamanie grzbietów ksiąg. Skaner PS70oo, poza tym, że przystosowany był do pracy w skali szarości, spełniał także wstępne wymogi dotyczące digitalizacji zasobu archiwalnego opracowane przez Bolesława Rassalskiego z Archiwum Państwowego w Bydgoszczy i Jana Szczygła z Archiwum Akt Nowych ${ }^{4}$, wśród których najważniejszą pozycję zajmowała wysoka rozdzielczość skanowania.

Wraz z zakupem wspomnianego skanera rozpoczął działalność dział digitalizacji w pracowni reprografii Archiwum. Digitalizacja w Archiwum Państwowym w Lublinie od początku była związana z dwoma zadaniami - ochroną dziedzictwa kulturowego przed zniszczeniem i udostępnianiem użytkownikom kopii cyfrowych. Przez ochronę należało tu rozumieć projekt skanowania archiwaliów najczęściej użytkowanych w celu uniknięcia dalszego ich niszczenia przy użytkowaniu, a udostępnianie użytkownikom miało odbywać się przez prezentację

${ }^{4}$ Decyzja nr 5 NDAP z 30 XII 2005 r., W sprawie standardów sporządzania cyfrowych kopii materiałów archiwalnych w Archiwach Państwowych. 
zeskanowanych archiwaliów na stronie internetowej Archiwum. Zadania te zostały zrealizowane tylko częściowo, co związane jest z problemami, które zaczęły się pojawiać w trakcie pracy, oraz poszukiwaniem metod ich rozwiązywania.

W latach 2002-2003 najważniejsze było poznanie możliwości skanera PS70oo. Działania podjęte $w$ tym okresie były nieco chaotyczne. Skanowano materiały prezentujące cały przekrój archiwaliów z lubelskiego Archiwum. W tym czasie został także zakupiony skaner płaski Mustek ScanExpress formatu $\mathrm{A}_{3}$, za pomocą którego na samym początku wykonano we fragmentach skany kilku wielkoformatowych map, połączone następnie w jeden plik dzięki wykorzystaniu oprogramowania graficznego dołączonego do skanera - podstawowej wersji Adobe Photoshop 5.5 LE. W związku ze wstępnym wyposażeniem pracowni w różnorodne typy urządzeń, pozwalające na skanowanie różnych rodzajów archiwaliów, rozpoczęto przymiarki do wprowadzenia digitalizacji planowej - czyli na potrzeby archiwum, w celu uchronienia zbiorów przed zniszczeniem, zwłaszcza tych najczęściej użytkowanych lub najbardziej narażonych na zniszczenie. W pierwszym podejściu digitalizacją planową został objęty zespół 35/632 Zbiór plakatów i druków ulotnych. Szybko jednak zrezygnowano z realizacji tego zadania ze względu na duży nakład czasu pracy na jeden obiekt. Jednocześnie przy użyciu skanera książkowego podjęto próbę digitalizacji planowej zespołu 35/9 Księgi grodzkie chełmskie, co także w niedługim czasie zostało zarzucone, gdyż ograniczony format i grubość ksiąg, które można było zeskanować na skanerze Minolta PS70oo, nie pozwalały na zachowanie ciągłości w skanowaniu. Równocześnie pojawił się pierwszy poważny problem w pracy pracowni digitalizacji - nazewnictwo plików. Poszukiwano rozwiązań, które objęlyby pliki tworzone podczas digitalizacji zarówno bieżącej, jak i planowej. Pierwsze próby stworzenia standardu nazewnictwa obejmowały twór złożony z takich elementów, jak: nr archiwum - nr zespołu - nr jednostki - nr strony/karty - rok wykonania skanów - nr płyty.

Mimo że szybko dokonano zmiany nazw dotychczas wykonanych skanów, konieczne okazało się porzucenie tego pomysłu, zwłaszcza w perspektywie nieuniknionej migracji danych na nowe nośniki, chociaż w Archiwum stosowano płyty z podkładem węglowym (tzw. czarne płyty), których okres trwałości był maksymalnie wydłużony. W ramach tego etapu wykonano skanowanie kilku pełnych jednostek, głównie z zespołów: 35/9 Księgi grodzkie chełmskie oraz z okresu II wojny światowej z zespołów 35/498 Urząd Okręgu Lubelskiego, 35/513 Centrala Przesiedleńcza Policji Bezpieczeństwa - Ekspozytura w Zamościu, 35/616 RGO - Polski Komitet Opiekuńczy Lublin Miasto i Powiat oraz 35/891 Rada Żydowska w Lublinie, które zajęły w sumie 8 płyt CD. Tak mała liczba jest związana ze wzrostem 
popularności kopii cyfrowych archiwaliów wśród użytkowników pracowni naukowej, co uniemożliwiało płynne realizowanie digitalizacji planowej. Warto nadmienić, że w latach 2002-2007 zadania digitalizacji zarówno bieżącej, jak i planowej realizował tylko jeden pracownik.

W 2003 r. ważnym elementem rozwoju digitalizacji w lubelskim Archiwum stało się wprowadzenie standardu nazewnictwa. Opis ten pokrywał się w dużej mierze z opisami ISAD $(G)$ i bazą SEZAM. Po raz pierwszy został zaprezentowany na spotkaniu zespołu „Informatyka i Archiwa” w Poznaniu w 2003 r. przez wydelegowanych wówczas pracowników Archiwum Państwowego w Lublinie. Spotkał się tam z uznaniem, dlatego - nie czekając na oficjalne zatwierdzenie i wprowadzenie jako wytycznej - zaczęto stosować go w lubelskim Archiwum. Zawierał następujące elementy: PL (kraj) - nr archiwum - nr zespołu - nr szczątku zespołu - sygnatura - nr karty - 1/2/o (recto, verso lub brak podziału przy zapisie jednostronnym).

Innym ważnym wydarzeniem w 2003 r. było zorganizowanie przez Archiwum pierwszego kursu digitalizacji dla pracowników bibliotek, archiwów, instytucji kulturalnych. Zajęcia praktyczne i teoretyczne, w oparciu o własne doświadczenia oraz przebyte w tym zakresie szkolenia, prowadzili Rafał Magryś, Marek Krzykała i Roman Kusyk. Podczas kursu zapoznano uczestników z teorią digitalizacji, jej zadaniami i etapami oraz efektywną obsługą sprzętu. W tym czasie podjęto także próby wprowadzenia standardu EAD (Kodowanego Opisu Archiwalnego), promowanego przez Naczelną Dyrekcję Archiwów Państwowych w ramach programu DELOS CEE, który to jednak standard z powodu braku kadr i nadmiaru zajęć związanych z digitalizacją bieżącą wciąż był odkładany i ostatecznie nie został wprowadzony.

Lata 2004 i 2005 to rozpoczęcie nowego zadania digitalizacji planowej - zeskanowania materiałów archiwalnych z zespołu 35/403/0/2 Urząd Wojewódzki Lubelski, Wydział Społeczno-Polityczny z okresu międzywojennego. Niestety zabrakło etapu przygotowania do skanowania, przez co - po zeskanowaniu blisko 70 jednostek (czyli wykonaniu ok. 10 tys. skanów) - trzeba było rozpocząć skanowanie od nowa po uprzednim rozszyciu jednostki i ustawieniu lepszego oświetlenia dla skanera. Doświadczenie to ujawniło braki w zakresie odpowiedniego przygotowania archiwaliów do digitalizacji oraz konieczność lepszego rozeznania rodzaju materiału, z jakim ma się do czynienia, jeszcze przed rozpoczęciem procesu zamiany na postać cyfrową.

$\mathrm{Na}$ tym etapie pracownia digitalizacji została wzbogacona o kolejny sprzęt aparat cyfrowy Minolta A1, 5 Mpx. Brakowało jednak profesjonalnego oświetlenia i stołu do fotografii, przez co sprzęt był wykorzystywany sporadycznie, raczej do 
tworzenia kopii poglądowych niż kopii zabezpieczających, nie spełniał bowiem wytycznych dotyczących rozdzielczości plików wynikowych. Wykonano nim np. fotografie prawie wszystkich planów i map z zespołu 35/22/o/13 seria Plany miasta Lublina, które wykorzystywane były m.in. jako dokumentacja konserwatorska w związku z tym, że większość tych planów trafiła do pracowni konserwacji w ramach planowanego wydawnictwa.

W październiku 2005 r. zorganizowano, tym razem przy wsparciu Naczelnej Dyrekcji Archiwów Państwowych, drugi kurs digitalizacji, w którym czynny udział wzięli archiwiści zajmujący się digitalizacją w archiwach.

Intensywny rozwój pracowni digitalizacji przypadł na lata 2006-2007. Przede wszystkim pracownia reprografii i digitalizacji zyskała nowe, przestronne pomieszczenie, w którym znalazło się miejsce zarówno dla wszystkich dotychczasowych, jak i nowych urządzeń, w tym dla profesjonalnej lustrzanki cyfrowej Nikon D2x $(12,3 \mathrm{Mpx})$. Nastąpiła wymiana skanera płaskiego A3 na nowy, Mustek Pro 3600 A3 z przetwornikiem cyfrowym CCD. W odróżnieniu od poprzedniego, z przetwornikiem typu CMOS, pozwalał on na skanowanie obiektów, które nie przylegają dokładnie do szyby, przez co nie było konieczności ich dociskania, a tym samym można było wyeliminować zagrożenie uszkodzenia archiwaliów. Aparat cyfrowy został zakupiony wraz z profesjonalnym oświetleniem i stołem do fotografii. Czas i wiele prób $\mathrm{z}$ różnymi rodzajami materiałów archiwalnych pokazały, że aparat idealnie sprawdza się w przypadku dokumentów wielkoformatowych, planów, map, plakatów, a także w digitalizacji bieżącej, gdy zachodzi potrzeba wykonania szybkiej kopii cyfrowej, w której wysoka jakość nie ma większego znaczenia. Wraz $\mathrm{z}$ aparatem pracownia digitalizacji Archiwum Państwowego w Lublinie została wzbogacona o nowy, wysoce wydajny i szybki jak na tamte czasy komputer oraz profesjonalne oprogramowanie do obróbki graficznej - Adobe Photoshop CS2, który to zestaw przyczynił się do znacznego usprawnienia i przyspieszenia pracy przy obróbce kopii cyfrowych materiałów archiwalnych. Zatrudniony został także, na część etatu, nowy pracownik do pracowni digitalizacji. Teoretycznie miało to przyspieszyć pracę pracowni dzięki podziałowi obowiązków, jednakże w niedługim czasie został on skierowany do innych zadań, przez co praktycznie wszystkie prace digitalizacyjne, zarówno bieżące, jak i planowe, spadły ponownie na jednego pracownika. W związku z tym, a także z powodu znacznego wzrostu popularności skanów wśród użytkowników pracowni naukowej, została zawieszona digitalizacja planowa ww. zespołu 35/403/o/2 Urząd Wojewódzki Lubelski. Wielka liczba zamówień z pracowni naukowej unieruchomiła działania planowe na kilka miesięcy, co wymusiło zmianę zadania na teoretycznie łatwiejsze i szybsze do 
zrealizowania. Podjęto więc skanowanie jednostek z zespołu 35/22/o/1 Akta miasta Lublina, a dokładniej serii Dokumenty miasta Lublina, z którego wybrano eksponaty możliwe do zaprezentowania podczas zbliżającej się wówczas 690. rocznicy lokacji miasta.

Przełom października i listopada 2007 r. wyznaczył nowy etap w działalności digitalizacyjnej Archiwum Państwowego w Lublinie. W tym czasie do pracowni digitalizacji skierowany został nowy pracownik, sama pracownia wzbogaciła się zaś o kolejny skaner - book2net firmy Microbox, umożliwiający skanowanie dokumentów do formatu A2, pracujący w 24-bitowej głębi kolorów i maksymalnej rozdzielczości 400 ppi oraz wyposażony w szybę dociskową i lampy LED o tzw. zimnym świetle, czyli pozbawionym promieniowania ultrafioletowego i promieniowania podczerwonego. Wraz z pojawieniem się nowego sprzętu poprzedni skaner, Minolta PS70oo, został wyłączony z digitalizacji planowej, zaś lustrzanka cyfrowa Nikon D2x oraz skaner płaski Mustek Pro 3600 zaczęły być wykorzystywane, $\mathrm{z}$ niewielkimi wyjątkami, tylko do digitalizacji bieżącej na potrzeby pracowni naukowej i kwerend. Zmianie uległ także podział obowiązków skanerzystów, jako że od listopada $2007 \mathrm{r}$. jeden $\mathrm{z}$ nich zajmował się wyłącznie digitalizacją bieżącą na potrzeby pracowni naukowej, drugi zaś tylko digitalizacją planową. Ten model przyjął się w lubelskim Archiwum od 2007 r. na stałe i wyznaczył jedną z podstaw organizacji procesu digitalizacji, którą Archiwum stosuje do dziś. Wraz z zakupionym skanerem powstała także pierwsza serwerownia $\mathrm{z}$ biblioteką taśmową do przechowywania skanów, które od końca 2007 r. zaczęly powstawać w liczbie niespotykanej w latach poprzednich. Pierwszym zespołem wytypowanym do digitalizacji planowej na nowym skanerze był zespół 35/1073 Bataliony Chłopskie Okręg IV Lublin, który zapoczątkował w 2008 r. digitalizację akt okupacyjnych, takich jak zespół 35/1072 Związek Walki Zbrojnej - Armia Krajowa Okręg Lublin czy zespół 35/1099 Zrzeszenie „Wolność i Niezawisłość” Okręg Lubelski. Pewnego rodzaju nowością związaną z digitalizacją zespołu 35/1073 Bataliony Chłopskie, było oddelegowanie jednego archiwisty do przygotowania tychże archiwaliów, co polegało na wyprostowaniu kart i ich spaginowaniu. Zaczęto tworzyć także pierwsze zasady kopiowania powstałych skanów na macierz dyskową i bibliotekę taśmową. Stopniowo zaczęło się kształtować pierwsze wyzwanie koordynacja pracy przygotowującego, skanerzysty oraz informatyka, aby zapewnić płynność digitalizacji zespołu. Dzięki sprawnej organizacji i komunikacji uniknięto problemu szybkiego kurczenia się przestrzeni dyskowej na co najmniej dwa lata (skany wykonywane były początkowo w rozdzielczości $400 \mathrm{ppi}$, co powodowało powstawanie względnie dużych plików). Warto nadmienić, że skaner book2net nie 
posiadał funkcji automatycznego kadrowania wykonanych skanów, a jedynie opcję określenia obszaru skanowania. Wymusiło to ręczne kadrowanie każdego skanu, co wykonywane było w programie Adobe Photoshop CS2. Każdy skan otrzymywał także unikatową nazwę, zgodnie z przyjętym szablonem. Wpływało to rzecz jasna na wyniki digitalizacji, jako że około $40 \%$ czasu przeznaczonego na nią zajmowało kadrowanie skanów i nadawanie nazw. Na początku 2009 r. zaczęto używać darmowego narzędzia do masowej zmiany nazw plików, co pozwoliło na zwiększenie wyników digitalizacji o około 10\%. Do tego czasu skanerzyści z lubelskiego Archiwum wypracowali kilka swoich zasad digitalizacji określonego rodzaju archiwaliów, jak np. szerokość czarnej obwódki wokół skanowanego dokumentu czy stosowanie czarnych i białych podkładów pod skanowane obiekty. Lata 2008-2010 upłynęły na digitalizacji głównie archiwaliów z zespołu 35/403/o/5 Urząd Wojewódzki Lubelski Wydział Komunikacyjno-Budowlany z okresu międzywojennego. Wielkoformatowe plany, rozkładane rzuty różnorodnych budowli oraz podłoża typu kalki technicznej stanowiły pewne wyzwanie logistycznie. Ostatecznie jednak Archiwum Państwowe w Lublinie wyniosło z niego nowe i cenne doświadczenie $\mathrm{w}$ pracy digitalizacyjnej. Bez zmian pozostała również praktyka kompleksowego przygotowywania materiałów przeznaczonych do digitalizacji przez jednego archiwistę, przy czym jednostki wymagające konserwacji właściwej były kierowanie do pracowni konserwacji archiwalnej. Nieco później włączono do paginowania także tych pracowników Archiwum, którzy zajmowali się przygotowaniem materiałów archiwalnych do udostępnienia w pracowni naukowej. Szczególnego wspomnienia wymaga 2009 r., w którym rozpoczęto wieloletnią, i wciąż trwającą, digitalizację jednego z największych zespołów w lubelskim Archiwum, 35/22 Akta miasta Lublina, począwszy od serii obejmujących dokumenty i księgi.

W 2010 r. ponownie uruchomiono skaner Minolta PS7000 w związku z tymczasowym przeniesieniem do pracowni digitalizacji jednego $\mathrm{z}$ archiwistów. Wprawdzie skaner umożliwiał tworzenie kopii cyfrowych jedynie w skali odcieni szarości, jednakże dopuszczono takie ograniczenie ze względu na rodzaj akt, które za jego pomocą miały być zdigitalizowane, a mianowicie akta stanu cywilnego. Ten rodzaj archiwaliów miał pozostać głównym punktem planów digitalizacji na wszystkich skanerach aż do końca 2013 r. Powoli jednak zaczął pojawiać się problem braku przestrzeni dyskowej do przechowywania wykonanych kopii cyfrowych. Wymusiło to konieczność używania dysków twardych komputerów znajdujących się w innych oddziałach Archiwum jako tymczasowych repozytoriów dla skanów. Nie trwało to jednak długo, ponieważ w grudniu $2010 \mathrm{r}$. Archiwum wzbogaciło się o nową macierz dyskową, a także o kolejny skaner - SCAN MASTER 1. Dofinansowany 
został ze środków Ministra Kultury i Dziedzictwa Narodowego w ramach projektu Zasoby cyfrowe, priorytet Digitalizacja materiałów archiwalnych i wraz ze wspomnianą macierzą dyskową stanowił rozbudowę infrastruktury digitalizacyjnej lubelskiego Archiwum. Rozdzielczość fizyczna do 600 ppi, 24-bitowa głębia kolorów, możliwość skanowania materiałów archiwalnych do formatu A1+, elektrycznie sterowane kołyski o wysokości do $35 \mathrm{~cm}$ oraz szybkość skanowania znacząco wpłynęły nie tylko na przyspieszenie prac digitalizacyjnych w latach następnych, ale również na kolejne zmiany w organizacji procesu digitalizacji. Przede wszystkim wyłączono $\mathrm{z}$ użytkowania $\mathrm{w}$ digitalizacji bieżącej skaner płaski i wkrótce po nim lustrzankę cyfrową, a zamówienia na skany zaczęto realizować na skanerze book2net. Przez cały następny rok dwa skanery pozwoliły na przyspieszenie prac digitalizacyjnych zarówno archiwaliów ze wspomnianego wcześniej zespołu 35/403 Urząd Wojewódzki Lubelski z okresu międzywojennego, jak i akt stanu cywilnego (kilkaset zespołów) oraz zespołu 35/22 Akta miasta Lublina, które miały pozostać głównymi materiałami archiwalnymi do digitalizacji wskazywanymi w planach digitalizacji na kilka kolejnych lat.

Kamieniem milowym w rozwoju pracowni digitalizacji lubelskiego Archiwum była druga połowa $2011 \mathrm{r}$. Był to czas wprowadzenia nowego zarządzenia Naczelnego Dyrektora Archiwów Państwowych w sprawie digitalizacji ${ }^{5}$ oraz pierwszej edycji Wieloletniego Programu Rządowego Kultura+, priorytet Digitalizacja, którego operatorem został Narodowy Instytut Audiowizualny. Archiwum Państwowe w Lublinie przystąpiło do napisania wniosku o dofinansowanie na zakup nowego sprzętu do digitalizacji oraz na wykonanie 150 tys. skanów z akt stanu cywilnego parafii rzymskokatolickich. Wniosek został rozpatrzony pozytywnie, dzięki czemu na przełomie 2011/2012 r. trzy nowe skanery - Zeutschel OS12000 A2, OS12000 HQ A2 oraz OS 14000 A1 stanęły w pracowni digitalizacji, a cyfrowe zasoby Archiwum powiększyły się o wspomniane 150 tys. skanów. W tym czasie sama pracownia digitalizacji przeszła gruntowny remont i modernizację wyposażenia, zgodnie z zaleceniami nowego zarządzenia Naczelnego Dyrektora ${ }^{6}$, poczynając od pomalowania ścian na kolor szary i wymiany drzwi, poprzez wymianę wykładzin, wstawienie regałów i nowych mebli biurowych, na zmianie konfiguracji oświetlenia i doborze profesjonalnego oświetlenia skończywszy. W pierwszej połowie 2012 r. Dyrektor Archiwum wydał także zarządzenie, które uszczegóławiało pro-

${ }^{5}$ Zarządzenie nr 13 NDAP z 29 VI 2011 r., w sprawie digitalizacji zasobu archiwalnego Archiwów Państwowych.

${ }^{6}$ Tamże. 
ces digitalizacji oraz wprowadzało bazę Digitalizacja służącą do ewidencji kopii cyfrowych na każdym etapie procesu digitalizacji ${ }^{7}$. W sierpniu $2012 \mathrm{r}$. lubelskie Archiwum otworzyło pracownię digitalizacji w swoim oddziale zamiejscowym w Radzyniu Podlaskim, do którego trafił dobrze sprawdzony w pięcioletniej pracy digitalizacyjnej skaner book2net. W wydzielonym pomieszczeniu utworzono pracownię digitalizacji i miejsce pracy oraz zapewniono instruktaż z zakresu obsługi skanera dla zatrudnionego pracownika. Dzięki nowemu wyposażeniu pracowni digitalizacji w 2012 r. w Archiwum Państwowym w Lublinie wykonano ponad 405 tys. skanów, z czego niemal połowę w ramach drugiej edycji WPR Kultura+, w której pozyskano także środki na zakup dwóch macierzy dyskowych do Centrali Archiwum o łącznej pojemności 216 TB. Warto nadmienić, iż wraz z udziałem w drugiej edycji WPR Kultura+ w Archiwum rozpoczęto sukcesywną kontrolę jakości wykonanych kopii cyfrowych poprzez wydelegowanie do tych czynności pracowników ówczesnej pracowni naukowej, zaś wykonywanie wskazanych poprawek paginacji i skanów uwzględniono przy planowaniu pracy digitalizacyjnej. W 2013 r. dostrzeżono również coraz bardziej naglącą potrzebę paginowania znacznej części archiwaliów przeznaczonych do digitalizacji, w związku z czym dyrektor Archiwum dodał do obowiązków służbowych archiwistów z oddziału gromadzenia i opracowania sukcesywne paginowanie archiwaliów przeznaczonych do digitalizacji. Kolejne lata przyniosły udział Archiwum w następnych edycjach WPR Kultura+, zaś dzięki środkom na inwestycje udało się, obok wykonania kopii cyfrowych dla pokaźnej części materiałów archiwalnych, głównie z akt stanu cywilnego, zakupić nowe skanery i rozbudować infrastrukturę informatyczną.

Trzecia edycja WPR Kultura+ w 2013 r. pozwoliła na zorganizowanie i uruchomienie pracowni digitalizacji na początku roku 2014 w oddziałach zamiejscowych w Chełmie i Kraśniku, gdzie pojawiły się skanery SMA SCAN MASTER 2 oraz dedykowane zestawy komputerowe, co podniosło tym samym ogólną liczbę pracowni digitalizacji Archiwum Państwowego w Lublinie do czterech. Również w 2014 r. Centrala wzbogaciła własny proces digitalizacji oraz doświadczenie w tej dziedzinie o etap przygotowania konserwatorskiego materiałów archiwalnych do digitalizacji, do realizacji którego dyrektor wyznaczył jednego z pracowników z pracowni konserwacji. Od tego momentu sam proces digitalizacji w Archiwum Państwowym w Lublinie miał już nie podlegać znaczącym zmianom i rozbudowaniu, z wyjątkiem niezbędnych modyfikacji w zależności od możliwości sprzętowych

7 Zarządzenie nr 2 Dyrektora Archiwum Państwowego w Lublinie (dalej DAPL) z 20 III 2012 r., w sprawie wprowadzenia procedury digitalizacji w Archiwum Państwowym w Lublinie. 
i kadrowo-organizacyjnych w danym roku kalendarzowym, jak np. udział praktykantów czy stażystów przy paginowaniu materiałów archiwalnych do digitalizacji. Czwarta edycja WPR Kultura+ w drugiej połowie 2014 r. była ostatnią, w której lubelskie Archiwum wnioskowało o zakup nowych skanerów. Nowy model sprawdzonego w latach poprzednich skanera SMA SCAN MASTER 1 oraz dwa skanery przelotowe Kodak i3250 Scanner stanęły w pracowni digitalizacji w Centrali Archiwum, wzbogacając bazę sprzętową i programową o nowe możliwości doboru materiałów archiwalnych do digitalizacji. Ostatnia edycja WPR Kultura+ w 2015 r. umożliwiła tak bardzo konieczną rozbudowę serwerowni Archiwum o nowe pomieszczenie i dodatkowe $160 \mathrm{~TB}$ przestrzeni dyskowej do przechowywania coraz szybciej narastającej liczby wytworzonych kopii cyfrowych materiałów archiwalnych. Zatrudnienie kolejnego pracownika do pracowni digitalizacji we wrześniu 2015 r., choć tylko na pół etatu, pozwoliło na niemalże maksymalne wykorzystanie skanerów i ich potencjału w digitalizacji różnorodnych archiwaliów. W tym samym roku wyszła także kolejna nowelizacja zarządzenia Naczelnego Dyrektora w sprawie digitalizacji zasobu archiwalnego archiwów państwowych, która obowiązuje do dziś. ${ }^{8}$. Rok 2016 i pierwsza połowa 2017 r. to dalszy rozwój doświadczenia lubelskiego Archiwum w dziedzinie digitalizacji, zwłaszcza na polu tworzenia kopii cyfrowych tych materiałów archiwalnych, które z racji swej formy i stanu fizycznego pozwoliły na ich skanowanie na skanerach przelotowych.

Wieloletnia praktyka Archiwum Państwowego w Lublinie w dziedzinie digitalizacji różnego rodzaju materiałów archiwalnych, począwszy od dokumentacji aktowej, przez techniczną i kartograficzną, na plakatach, afiszach i fotografiach skończywszy, stanowi cenny dorobek, którym lubelskie Archiwum dzieli się z innymi archiwami i instytucjami w ramach wymiany doświadczeń. Szkolenia, konferencje, a zwłaszcza dedykowane Dni Digitalizatora organizowane od kilku lat przez Narodowe Archiwum Cyfrowe, są nieodmiennie przestrzenią i czasem, w których lubelskie Archiwum zajmuje ważne i zasłużone miejsce, a podejmując nowe wyzwania digitalizacyjne, stara się poszerzać i aktualizować swoją 15-letnią wiedzę w dziedzinie tworzenia wiernych odwzorowań cyfrowych materiałów archiwalnych, zwanej digitalizacją.

${ }^{8}$ Zarządzenie nr 14 NDAP z 31 VIII 2015 r., w sprawie digitalizacji zasobu archiwalnego Archiwów Państwowych (dalej Zarządzenie nr 14). 


\section{Organizacja procesu digitalizacji}

Archiwum Państwowe w Lublinie wyposażone jest w profesjonalne skanery dziełowe (książkowe) oraz przelotowe, których parametry i możliwości techniczne są najlepiej przystosowane do tworzenia kopii cyfrowych $\mathrm{z}$ wszelkich form dokumentacji aktowej. Obecnie ${ }^{9}$ w Archiwum lubelskim znajduje się siedem skanerów:

- SMA SCAN MASTER 1 (skaner dziełowy A1; zakupiony w 2010 r. ze środków Ministra Kultury i Dziedzictwa Narodowego w ramach programu Zasoby cyfrowe, priorytet Digitalizacja materiałów archiwalnych);

- Zeutschel OS 14000 A1 (skaner dziełowy A1; zakupiony w 2011 r. ze środków Ministra Kultury i Dziedzictwa Narodowego w ramach Wieloletniego Programu Rządowego Kultura +, priorytet Digitalizacja);

- Zeutschel OS 12000 A2 (skaner dziełowy A2; zakupiony w 2011 r. w ramach WPR Kultura +);

- Zeutschel OS 12000 HQ A2 (skaner dziełowy A2; zakupiony w $2011 \mathrm{r}$. w ramach WPR Kultura + );

- SMA SCAN MASTER 1 (skaner dziełowy A1; zakupiony w 2014 r. w ramach kolejnej edycji WPR Kultura + );

- Kodak i3250 Scanner (dwa skanery przelotowe A3; zakupione w 2014 r. w ramach WPR Kultura + ).

Dodatkowo oddziały zamiejscowe lubelskiego Archiwum posiadają następujące skanery:

- Radzyń Podlaski: Microbox book2net (skaner dziełowy A2; zakupiony przez lubelskie Archiwum w 2007 r. dzięki wsparciu finansowemu Ministra Kultury i Dziedzictwa Narodowego (do oddziału został przekazany W 2012 r.);

- Kraśnik: SMA SCAN MASTER 2 (skaner dziełowy A2; zakupiony w 2013 r. w ramach edycji WPR Kultura + );

- Chełm: SMA SCAN MASTER 2 (jw.).

Wszystkie wymienione wyżej skanery spełniają wymogi stawiane przed sprzętem do digitalizacji materiałów archiwalnych związane $\mathrm{z}$ wartością ich rozdzielczości fizycznej, głębi koloru zapisywanych obrazów cyfrowych, gęstości optycznej,

\footnotetext{
${ }^{9}$ Stan na wrzesień $2017 \mathrm{r}$.
} 
jak również wymagania dotyczące formatów plików oraz możliwości zapisywania metadanych technicznych charakteryzujących parametry skanowania ${ }^{10}$.

W ścisłym związku $\mathrm{z}$ bazą sprzętową $\mathrm{w}$ postaci skanerów jest wyposażenie samej pracowni digitalizacji oraz jej organizacja. Zestawy komputerowe, przeznaczone do obsługi skanerów i wytworzonych kopii cyfrowych, charakteryzują się wysokimi parametrami technicznymi oraz profesjonalnym oprogramowaniem, co ma szczególne znaczenie w przypadku bieżącej kontroli jakości wykonywanych kopii cyfrowych oraz ich ewentualnej, późniejszej obróbki, jak np. kadrowanie czy niezbędne łączenie kilku skanów w jeden. Stanowiska pracy rozmieszczone są w sposób uniemożliwiający szkodliwą interferencję oświetlenia pochodzącego z sąsiednich skanerów oraz oświetlenia biurowego, a każde stanowisko, czyli skaner, szerokie biurko i krzesło obrotowe, jest ustawione w kształcie litery „L”. Takie ustawienie pozwala zmaksymalizować ergonomię pracy skanerzysty oraz zapewnia łatwy dostęp zarówno do sprzętu, jak i do skanowanych dokumentów, zwłaszcza $\mathrm{w}$ postaci akt luźnych ${ }^{11}$. Pracownia wyposażona jest $\mathrm{w}$ metalowe regały do przechowywania przygotowanych do digitalizacji oraz zdigitalizowanych jednostek aktowych, a także szafki ze środkami ochrony osobistej. Znajduje się w niej również wydzielone pomieszczenie dla konserwatora, wyposażone w specjalistyczną prasę, suszarkę do akt i materiały konserwatorskie. Kolorystyka pomieszczeń pracowni utrzymana jest w odcieniach szarości (włącznie z roletami na oknach), a do jej oświetlenia stosowane są świetlówki Philips MASTER TL-D 9o Graphica $58 \mathrm{~W} / 950$ 1SL o temperaturze barwowej $5300 \mathrm{~K}^{12}$. Tak wyposażona i zorganizowana pracownia digitalizacji pozwala na sprawne, efektywne i komfortowe skanowanie materiałów archiwalnych, bez względu na ich postać i format.

Nie mniej istotnym elementem organizacji procesu digitalizacji archiwaliów jest odpowiednio dobrana i wykwalifikowana kadra pracownicza. Zarówno w lubelskim Archiwum, jak i w jego oddziałach zamiejscowych stanowią ją archiwiści (przygotowanie archiwaliów do skanowania) oraz skanerzyści i kontrolerzy, którzy posiadają kwalifikacje zdobyte $\mathrm{w}$ ramach certyfikowanych szkoleń $\mathrm{z}$ digitalizacji,

10 Zarządzenie nr 14 .

11 Spotyka się także ustawienie szeregowe, w którym skaner i biurko znajdują się obok siebie. Takie ustawienie wydaje się jednak mniej ergonomiczne $\mathrm{z}$ racji oddalenia monitora od oczu operatora skanera (jeśli sam skaner nie jest wyposażony w monitor umieszczony np. na jego kolumnie) oraz niewygody przy przechodzeniu od skanera do biurka.

12 Pracownia digitalizacji Archiwum Państwowego w Lublinie, jak również pracownie w jego oddziałach zamiejscowych spełniają wymagania dotyczące ich przygotowania do prowadzenia digitalizacji określone w $\$ 10$ ust. 1 Zarządzenia nr 14. 
przeprowadzonych przez Narodowe Archiwum Cyfrowe, które decyzją Ministra Kultury i Dziedzictwa Narodowego z 15 X 2009 r. zostało ustanowione Centrum Kompetencji w zakresie digitalizacji materiałów archiwalnych ${ }^{13}$. Kwalifikacje skanerzystów lubelskiego Archiwum są rozwijane także przez ich czynny udział w corocznych Dniach Digitalizatora, organizowanych przez NAC, będących forum wymiany doświadczeń między archiwami państwowymi. Niemałe znaczenie mają również długoletnie doświadczenie osób uczestniczących w procesie digitalizacji oraz praca na zróżnicowanych i niejednokrotnie trudnych do skanowania materiałach archiwalnych, jak np. księgi z wysokim grzbietem i głęboko wszytym tekstem, poszyty różnoformatowe, wielkoformatowe mapy, plakaty czy pieczęcie.

Ostatnim elementem omawianej organizacji są procedury związane z przebiegiem procesu digitalizacji materiałów archiwalnych. W przytaczanym już Zarządzeniu nr 14 wskazane zostały w sposób pośredni następujące etapy tego procesu:

- Selekcja materiałów archiwalnych do digitalizacji

- Przygotowanie materiałów archiwalnych

- Digitalizacja (skanowanie)

- Tworzenie katalogów i nazewnictwo plików cyfrowych

- Kontrola jakości kopii cyfrowych

- Zabezpieczenie wzorcowych kopii cyfrowych

- Udostępnianie użytkowych kopii cyfrowych ${ }^{14}$.

Wspomniane wyżej zalecenia regulują podstawowe kwestie dotyczące przeprowadzania procesu digitalizacji, jak np.: zasady selekcji i przygotowania archiwaliów, opis archiwalny, sprzęt do digitalizacji, parametry kopii cyfrowych czy struktura katalogów i opisu tychże kopii. Zarządzenie nr 14 nie określa natomiast szczegółowych procedur postępowania na kolejnych etapach procesu digitalizacji, pozostawiając $\mathrm{w}$ gestii dyrektorów poszczególnych archiwów państwowych przygotowanie szczegółowych instrukcji w tej kwestii ${ }^{15}$.

${ }^{13}$ Omówienie kompetencji Narodowego Archiwum Cyfrowego (dalej NAC) w tej materii można znaleźć w: Ł. Skowron, Narodowe Archiwum Cyfrowe jako centrum kompetencji w zakresie digitalizacji materiałów archiwalnych - podsumowanie dwóch lat działalności, „Archiwista Polski” T. 3, 2012, s. 97-104.

${ }^{14}$ Inne ujęcie etapów procesu digitalizacji można znaleźć w książce: Digitalizacja piśmiennictwa, red. D. Paradowski, Warszawa 2010. W części poświęconej prowadzeniu digitalizacji (s. 155-202) etapy te są następujące: planowanie obiektów i określanie priorytetów; pobieranie obiektów do digitalizacji; transport; weryfikacja i ustalenie parametrów; skanowanie; przetwarzanie i gromadzenie obiektów cyfrowych; udostępnianie.

15 Zarządzenie $\mathrm{nr} 14, \S 6$, ust. 1. 
Dyrektor Archiwum Państwowego w Lublinie w drodze zarządzenia z dn. 20 III 2012 r. wprowadził szczegółowe procedury digitalizacji, w których określone zostały zasady postępowania $\mathrm{w}$ procesie digitalizacji materiałów archiwalnych $\mathrm{w}$ lubelskim Archiwum, w zgodzie z zapisami obowiązującego wówczas Zarządzenia $\mathrm{nr} 13 \mathrm{z}$ dn. 29 VI 2011 r. Szczególnie ważny w zarządzeniu Dyrektora lubelskiego Archiwum jest wspomniany wcześniej w niniejszym artykule zapis o utworzeniu bazy Digitalizacja, służącej do zarządzania procesem digitalizacji na wszystkich jego etapach. Baza ta stała się podstawowym narzędziem do ewidencji i kontroli zdigitalizowanych zespołów i jednostek archiwalnych. Dzięki niej możliwe są takie funkcjonalności jak: szczegółowy opis zdigitalizowanej jednostki archiwalnej na każdym etapie procesu digitalizacji, określenie zadań i kompetencji poszczególnych osób biorących udział w procesie digitalizacji, opracowanie planów digitalizacji, czy sporządzanie dokumentacji dotyczącej wytworzonych kopii cyfrowych ${ }^{16}$. Baza Digitalizacja została napisana w języku PHP (obiektowy język programowania) przez informatyka zatrudnionego w lubelskim Archiwum, dzięki czemu stanowi ona darmowe narzędzie do zarządzania archiwaliami przeznaczonymi do digitalizacji. Jest zbudowana w oparciu o moduły, do których dostęp zależny jest od stopnia uprawnień użytkownika oraz funkcji, jakie spełnia on w procesie digitalizacji.

Wspomniane moduły to:

- Całość admin - dostępny dla administratora systemu informatycznego oraz koordynatora procesu digitalizacji. Umożliwia dostęp do wszystkich rekordów w bazie wraz z możliwością ich edytowania. Usuwanie rekordów $\mathrm{z}$ bazy zarezerwowane jest wyłącznie dla administratora;

- Całość - dostępny dla wszystkich użytkowników bazy. Umożliwia podgląd wszystkich rekordów w bazie bez możliwości ich edytowania;

- Przygotowanie jednostek - dostępny dla osób zaangażowanych w przygotowanie jednostek do digitalizacji na poziomie paginowania i podstawowego opisu;

- Skanowanie - dostępny dla operatorów skanerów;

- Kontrola skanów - dostępny dla kontrolerów wykonanych kopii cyfrowych;

- Raporty - dostępny dla wszystkich użytkowników bazy. Pozwala na dokonanie ogólnego i szczegółowego zestawienia zdigitalizowanych zespołów oraz jednostek archiwalnych według zadanych kryteriów wyszukiwania.

16 Załącznik nr 1 do Zarządzenia nr 2/2012 DAPL z 20 III 2012 r., Procedura digitalizacji w Archiwum Państwowym w Lublinie, rozdz. 7. 
Struktura modułów bazy Digitalizacja wskazuje na cztery podstawowe funkcje, jakie mogą być przypisane odpowiednim pracownikom archiwum. Są to:

- administrator bazy

- osoba przygotowująca

- skanerzysta

- kontroler.

W praktyce digitalizacyjnej Archiwum Państwowego w Lublinie funkcje te $\mathrm{z}$ reguły nie podlegają łączeniu, $\mathrm{z}$ wyjątkiem sytuacji, $\mathrm{w}$ których decydujące znaczenie mają czynniki organizacyjne i kadrowe. Nie stanowi to jednak trudności, o ile dany pracownik spełnia odpowiednie wymagania do pełnienia tych funkcji.

Podstawową funkcjonalnością bazy jest opis jednostek archiwalnych przeznaczonych do digitalizacji, a więc podanie takich informacji, które nie tylko pozwalają na zidentyfikowanie każdej jednostki w bazie, ale także umożliwiają śledzenie jej na każdym etapie procesu digitalizacji, od momentu jej przygotowania (spaginowania i opisania) aż do udostępnienia w Internecie na portalu szukajwarchiwach.pl. Przekłada się to bezpośrednio na strukturę rekordu, który zawiera następujące pola:

- nazwa zespołu;

- numer zespołu;

- c. d. numeru (tylko w przypadku zespołów szczątkowych);

- seria (włącznie z podseriami, jeśli istnieją);

- sygnatura;

- numer mikrofilmu;

- liczba stron (kart w przypadku foliacji);

- liczba skanów;

- osoba przygotowująca jednostkę;

- data przygotowania jednostki;

- operator skanera;

- data wykonania skanów;

- wielkość plików tiff (kopia wzorcowa, zabezpieczająca);

- wielkość plików jpg (kopia użytkowa);

- kontroler skanów;

- data kontroli skanów;

- rodzaj digitalizacji (wykonywana w ramach działań statutowych bądź przez udział w różnych programach, np. Wieloletnim Programie Rządowym Kultura+ czy programach z Naczelnej Dyrekcji Archiwów Państwowych); 
- rodzaj obrazu (nagrania dźwiękowe, obrazy nieruchome, obrazy ruchome, tekstowe);

- rodzaj jednostki (aktowa, fotograficzna, kartograficzna, techniczna, ulotna);

- centralne repozy torium cyfrowe (informacja o zabezpieczeniu w CRC NAC);

- szukajwarchiwach.pl (informacja o zamieszczeniu na portalu);

- lokalizacja na serwerze;

- kopia użytkowa (jej istnienie bądź brak);

- uwagi (dotyczące cech stanu fizycznego jednostki, które utrudniają wykonanie i odczytanie skanów);

- inne (informacje niemieszczące się w zakresie poprzednich pól) ${ }^{17}$.

Wpisywaniem danych do powyższych pól zajmują się pracownicy pełniący określone funkcje, przy czym najważniejsze dane opisowe wprowadzają osoby przygotowujące jednostki do digitalizacji. Kompletność i przejrzystość danych zawartych w bazie Digitalizacja pozwalają na pełną kontrolę postępu digitalizacji poszczególnych zespołów archiwalnych i są kluczowe dla sprawnego przebiegu całego procesu.

\section{Etapy procesu digitalizacji}

Pierwszym etapem w złożonym procesie digitalizacji jest selekcja materiałów archiwalnych, która jest niezbędna do utworzenia planu digitalizacji (wieloletniego i rocznego), będącego podstawą organizacji całego procesu. Główne zasady

17 Zarządzenie nr 13 NDAP z 29 VI 2011 r., W sprawie digitalizacji zasobu archiwalnego Archiwów Państwowych, w $\$ 8$ nakładało na dyrektorów archiwów państwowych obowiązek zapewnienia należytych warunków prowadzenia w ich jednostkach ewidencji kopii cyfrowych materiałów archiwalnych, odpowiadającej zaleceniom. Obecnie obowiązujące Zarządzenie nr 14 $\mathrm{w} \$ 18$ wskazuje na obowiązek prowadzenia takiej ewidencji kopii cyfrowych, która powinna zawierać co najmniej następujące dane w odniesieniu do jednostki archiwalnej: numer archiwum; numer zespołu wraz z ciągiem dalszym numeru zespołu; oznaczenie serii; sygnaturę; liczbę wykonanych kopii wzorcowych (plików) z oryginału materiału archiwalnego; liczbę wykonanych kopii wzorcowych (plików) z mikrofilmu; rozmiar kopii wzorcowych w GB; osobę/podmiot odpowiedzialny za kopiowanie; datę kopiowania w układzie rok-miesiąc-dzień; finansowanie digitalizacji (budżet własny/program - jaki?/inne - jakie?, np. pozyskane w postaci daru lub zakupu); status kontroli jakości: do kontroli jakości/skontrolowano; status udostępnienia on-line: nie do udostępnienia/do udostępnienia/udostępniono; status zabezpieczenia: przekazano do CRC AP (Centralne Repozytorium Cyfrowe Archiwów Państwowych); źródło finansowania (budżet własny, inne - jakie?); uwagi. 
selekcji archiwaliów określa Zarządzenie nr 14, którego zapisy dopuszczają do digitalizacji jedynie te materiały archiwalne, które posiadają ewidencję w systemie informatycznym ${ }^{18}$, a także ustalają priorytet digitalizacji dla archiwaliów o najwyższej wartości historycznej, znajdujących się w złym stanie fizycznym, często użytkowanych i udostępnianych, wskazanych $z$ innych przyczyn przez Naczelnego Dyrektora lub objętych roszczeniami w zakresie prawa własności ${ }^{19}$. W praktyce digitalizacyjnej Archiwum Państwowego w Lublinie dobór materiałów archiwalnych zgodnie z powyższymi kryteriami jest dodatkowo uwarunkowany oceną tychże materiałów przez konserwatora oraz koordynatora procesu digitalizacji w zakresie możliwości technicznych i czasowych ich przygotowania oraz wykonania z nich kopii cyfrowych, co jest niezbędne przy określaniu liczby skanów, jaka będzie możliwa do uzyskania w kolejnych latach działalności. Także przewidywana liczba pracowników zajmujących się przygotowaniem i skanowaniem materiałów archiwalnych, jak i dostępna baza sprzętowa w pracowni digitalizacji wpływają istotnie na selekcję materiałów archiwalnych, ponieważ nieuwzględnienie tych czynników może skutkować (i najczęściej skutkuje) niemożliwymi do zrealizowania, pod względem liczby wykonanych skanów, planami digitalizacji. Jednostki archiwalne, które na etapie selekcji zostały przekazane do pracowni konserwacji, zostają wpisane do planu digitalizacji, jeśli ich konserwacja będzie możliwa do wykonania $\mathrm{w}$ danym roku działalności digitalizacyjnej. W przeciwnym wypadku ich digitalizacja zostaje odłożona do czasu wykonania niezbędnych napraw konserwatorskich ${ }^{20}$.

18 Zarządzenie nr 14, $\$$, ust. 1.

19 Tamże, ust. 4-5.

20 Załącznik nr 4 do Zarządzenia nr 14 wprowadza kryteria oceny stanu materiałów archiwalnych przed digitalizacją, które pokrywają się z dotychczasową praktyką lubelskiego Archiwum. Materiały te zostały podzielone na 4 grupy. Grupa 0: Jednostka archiwalna może być przekazana do digitalizacji bez jakichkolwiek ingerencji konserwatorskich. Istniejące uszkodzenia nie mają wpływu na jakość skanowania. 100\% informacji jest czytelne. Grupa 1: Przed wykonaniem skanowania niezbędna jest niewielka interwencja konserwatora - prostowanie, reperacje (do ok. 10 kart) w miejscach, gdzie zasłonięty jest tekst. Grupa 2: Jednostka archiwalna w średnim stanie - wymaga prac bardziej rozległych. Liczne karty uszkodzone i pozaginane w sposób uniemożliwiający digitalizację. Konieczne usunięcie reperacji zasłaniających tekst. Grupa 3: Jednostka archiwalna, której nie można poddać digitalizacji bez uprzedniego podjęcia długotrwałych i zaawansowanych prac konserwatorskich. Duże fragmenty tekstu są zasłonięte, niezbędne jest usunięcie dawnych reperacji. Liczne ubytki i przedarcia w partii tekstu. Destrukt. Nie ma możliwości pominięcia etapu konserwacji, gdyż w obecnym stanie wykonanie digitalizacji nieodwracalnie pogłębi uszkodzenia. Ponadto znaczna część informacji nie zostanie podczas skanowania zarejestrowana. 
Zapewnienie sprawnej realizacji planu digitalizacji na kolejnych etapach procesu, którymi są przygotowanie jednostek oraz ich skanowanie, należy do obowiązków koordynatora procesu digitalizacji. Na etapie przygotowania wypożycza on określone jednostki archiwalne z magazynu w liczbie zapewniającej ciągłość pracy osób zajmujących się przygotowaniem oraz przekazuje je tym osobom, po uprzednich konsultacjach $\mathrm{z}$ ich kierownikami w sprawie organizacji pracy przygotowawczej oraz jej wymiaru czasowego. W lubelskim Archiwum przygotowaniem jednostek do digitalizacji zajmują się głównie archiwiści pracujący w oddziale gromadzenia i opracowania zasobu oraz $\mathrm{w}$ oddziale informacji archiwalnej. W mniejszym wymiarze czasu przygotowaniem jednostek zajmują się także osoby obsługujące magazyny archiwalne, pracownicy czytelni (dawnej pracowni naukowej) oraz osoby związane z obsługą portierni, jeśli dane jednostki archiwalne nie wymagają specjalistycznej wiedzy merytorycznej związanej z ich przygotowaniem (jak np. akta Trybunału Koronnego, czy tzw. kancelarii rosyjskiej). Do przygotowania jednostek dopuszcza się także praktykantów studiów historycznych, wolontariuszy oraz stażystów, po uprzednim przeszkoleniu ich w zakresie zasad paginowania i opisu stanu fizycznego oraz zapewnieniu im opieki merytorycznej.

Osoba przygotowująca jednostkę archiwalną do digitalizacji po jej spaginowaniu wprowadza rekord do bazy Digitalizacja. Składa się on z następujących danych: kompletny numer zespołu wraz z serią i sygnaturą, liczba stron, data przygotowania jednostki, rodzaj jednostki, rodzaj digitalizacji, opis stanu fizycznego jednostki oraz, jeśli to konieczne, uwagi dodatkowe. Warto zwrócić uwagę na fakt, iż baza Digitalizacja zawiera zaimportowane z ZoSIA (Zintegrowanego Systemu Informacji Archiwalnej) numery i nazwy zespołów archiwalnych lubelskiego Archiwum, dzięki czemu nazwa zespołu w bazie jest uzupełniana automatycznie po wpisaniu jego numeru przez osobę dokonującą wpisu. Istotnym elementem opisu jednostki przeznaczonej do digitalizacji są informacje o takich cechach jej stanu fizycznego, które wpływają na jakość i wierność odwzorowania cyfrowego. Bez tych informacji trudno określić, czy zaistniałe zaburzenia wynikają z błędu skanerzysty, nieprawidłowej kalibracji sprzętu do digitalizacji czy też cech wspomnianego stanu fizycznego jednostki, której wierne odwzorowanie na skanie jest niemożliwe. Tymi cechami są przede wszystkim: głębokie szycie lub klejenie zasłaniające tekst, uszkodzenie kart, karty zachowane fragmentarycznie, pieczęcie zachowane luzem, pieczęcie zasłaniające tekst, przycięcie bloku księgi razem z tekstem, ślady po przesznurowaniu w tekście, tekst nieczytelny, wadliwe naprawy konserwatorskie, zaburzenie kolejności pism wynikające $\mathrm{z}$ wadliwego zszycia. Osoba przygotowująca jednostkę do digitalizacji ma możliwość określenia 
w bazie Digitalizacja stron lub ich przedziałów, na których występują powyższe cechy stanu fizycznego jednostki, dzięki czemu ułatwia ona pracę operatora skanera oraz kontrolera, jak również podnosi komfort korzystania z użytkowych kopii cyfrowych danej jednostki, ponieważ informacje przez nią podane zamieszczone zostają na metryczce wewnątrz katalogu z kopiami cyfrowymi zdigitalizowanej jednostki. Warto także zaznaczyć, iż baza nie dopuszcza do powstawania duplikatu rekordu, gdy wpisywany numer zespołu, pełna seria i sygnatura już się w niej znajdują. Szczególnie istotna jest zgodność serii i podserii, ponieważ w przypadku niektórych zespołów akt przeznaczonych do digitalizacji każda seria zawiera odrębną numerację sygnatur.

W celu utrzymania ciągłości pracy skanerzystów dyrektor lubelskiego Archiwum ustalił dzienną normę dla osób przygotowujących materiały archiwalne na poziomie 120 stron. Norma ta uwzględnia zarówno możliwości kadrowe i czasowe poszczególnych oddziałów, jak i zapotrzebowanie na przygotowane jednostki archiwalne ze strony operatorów skanerów. Wspomnieć należy, że nie wszystkie archiwalia wymagają paginowania kart, a jedyną czynnością w ich wypadku jest sprawdzenie istniejącej paginacji pod względem jej poprawności. Szczegółowe zasady paginowania, takie jak miejsce stawiania numerów stron, postępowanie $\mathrm{z}$ foliacją czy z wcześniejszą, błędną paginacją, reguluje Zarządzenie $\mathrm{nr} 14^{21}$.

Po przygotowaniu jednostek archiwalnych i wpisaniu do bazy Digitalizacja odpowiednich danych, trafiają one do pracowni digitalizacji. W przypadku jednostek, które wymagają rozszycia, wyprostowania kart, usunięcia części metalowych oraz dokonania drobnych napraw konserwatorskich, koordynator procesu digitalizacji (lub operatorzy skanerów w przypadku, gdy uszkodzenia i zagniecenia kart wystąpiły w trakcie digitalizacji) przekazuje wskazane jednostki do konserwatora. Dzięki temu, że znajduje się on w pracowni digitalizacji, wymiana informacji oraz organizacja pracy związanej z wymogami konserwatorskimi danych jednostek przebiegają sprawnie i pozwalają na elastyczność w planowaniu pracy poszczególnych operatorów skanerów. Gdy jednostki archiwalne są gotowe do skanowania, koordynator rozdziela je pomiędzy poszczególnych skanerzystów. Uwzględnia przy tym rodzaj materiałów archiwalnych (akta luźne, poszyty, księgi, obiekty wielkoformatowe jak plany, afisze), możliwości sprzętowe skanerów i ich oprogramowania oraz ewentualną konieczność wykonania dodatkowych czynności związanych z kopiami cyfrowymi, jak np. łączenie ich w programie graficznym czy niezbędna obróbka w postaci prostowania i kadrowania w przypadku, gdy

\footnotetext{
${ }^{21}$ Zarządzenie nr 14, $\$ 8$, ust. 1, pkt 5.
} 
oprogramowanie skanera nie wykonuje ich automatycznie. Szczególną uwagę należy zwrócić na wspomniane wyżej możliwości sprzętowe skanerów oraz ich oprogramowania, ponieważ to od nich w znacznej mierze zależy czas wykonania skanów, jak również ich jakość w przypadku, gdy oprócz parametrów związanych z rozdzielczością i głębią bitową istotną rolę odgrywają oferowana przez skaner głębia ostrości oraz równomierność oświetlenia skanowanego obiektu. Za przykład niech posłużą księgi z głębokim wszyciem tekstu i grzbietem wyższym niż objętość ich kart. Po ułożeniu ich na szalkach skanera dziełowego (książkowego), który nie pozwala na równomierne oświetlenie obszarów oddalonych od poziomu skanowania (wyznaczonego przykładowo przez szybę dociskową), karty i tekst położone na niższym poziomie będą widoczne na skanie jako miejsca zaciemnione i nieostre, co automatycznie eliminuje taki skan jako odwzorowanie cyfrowe.

Rozdzielanie jednostek archiwalnych do digitalizacji opiera się w lubelskim Archiwum najczęściej na zasadzie „jeden zespół archiwalny - jeden skanerzysta", co ma miejsce w przypadku równoczesnego skanowania kilku niewielkich zespołów. Zasada ta umożliwia lepszą kontrolę skanowania kolejnych jednostek z danego zespołu i sprawniejszą organizację pracy zespołu zaangażowanego w proces digitalizacji, a zwłaszcza osób związanych z przygotowaniem jednostek oraz ich niezbędną konserwacją. Nieraz nawiązuje się także współpraca pomiędzy kilkoma osobami przygotowującymi określony zespół archiwalny i jednym skanerzystą odpowiedzialnym za jego zeskanowanie, choć jest to, w dotychczasowym doświadczeniu Archiwum, sytuacja rzadko spotykana. Niemniej jednak takie rozwiązanie ułatwia pracę koordynatorowi i pozwala przekazać część zadań związanych z digitalizacją danego zespołu ww. osobom.

Skanowanie jednostki archiwalnej rozpoczyna się od przygotowania sprzętu ${ }^{22}$, utworzenia roboczego katalogu docelowego oraz ustalenia parametrów wyjściowych kopii zabezpieczających. Nazwa katalogu składa się z następujących elementów:

- <numer zespołu>_<sygnatura > w przypadku zespołów z ciągłością sygnatur;

- <numer zespołu $>$ _seria $>$ _sygnatura $>$ w przypadku zespołów $z$ odrębnym ciągiem sygnatur w poszczególnych seriach;

- <numer zespołu>_<c. d. numeru zespołu>_<sygnatura > w przypadku zespołów szczątkowych.

${ }^{22}$ Wskazówki dotyczące kalibracji sprzętu do digitalizacji zawiera Załącznik nr 2 do Zarządzenia nr 14 . 
Roboczy charakter mają także nazwy poszczególnych skanów, ponieważ stanowi je wyłącznie numer kolejny licznika, składający się z czterech cyfr, z pominięciem innych elementów opisu. Przedstawiony model nazewnictwa ma charakter czasowy i zostaje zmieniony przez administratora systemu informatycznego na następnym etapie procesu.

Parametry wyjściowych kopii zabezpieczających dla wszystkich materiałów archiwalnych, bez względu na ich rodzaj, formę i treść, przyjmują następujące wartości:

- rozdzielczość (na całej powierzchni skanowania): 300 ppi;

- format zapisu: TIFF 6.0 bez kompresjii ${ }^{23}$;

- głębia kolorów: 24-bitowe RGB.

Wyjątek stanowią materiały, które ze szczególnych względów (np. konieczność wykonania znacznego powiększenia niewielkich fotografii) wymagają stosowania wyższych rozdzielczości (do 600 ppi).

Podczas skanowania operator skanera na bieżąco kontroluje poprawność paginacji w jednostce archiwalnej oraz poprawność odwzorowania na skanach jej poszczególnych stron ${ }^{24}$. W przypadku stwierdzenia błędu w paginacji operator skanera wstrzymuje skanowanie jednostki i zwraca ją właściwej osobie przygotowującej w celu dokonania korekty. Błędnie naniesiona przez nią paginacja zostaje wymazana i zastąpiona poprawną, po czym osoba przygotowująca zwraca jednostkę bezpośrednio do właściwego skanerzysty. Wszelkie błędy w odwzorowaniu stron poprawiane są przez operatora skanera na bieżąco, natomiast cechy stanu fizycznego jednostki, które uniemożliwiają zeskanowanie całości informacji lub wpływają na jakość skanu, zostają wykazane przez operatora w bazie Digitalizacja, jeśli nie dokonała tego (bądź dokonała tylko fragmentarycznie) osoba przygotowująca.

Po zdigitalizowaniu jednostki archiwalnej skanerzysta wpisuje do bazy Digitalizacja następujące dane: liczba skanów, wielkość plików tif, data wykonania skanów, operator skanera, rodzaj obrazu oraz uwagi (dodatkowe w stosunku do zapisanych przez osobę przygotowującą jednostkę). Na obwolucie jednostki (lub okładce w przypadku jej braku) skanerzysta stawia pieczątkę „zdigitalizowano”, która służy informowaniu magazynierów o istnieniu jej kopii cyfrowej. Jeżeli

${ }^{23}$ Załącznik nr 1 do Zarządzenia $\mathrm{nr} 14$ dopuszcza możliwość stosowania również formatu TIFF 6.o z kompresją bezstratną LZW (Lempel-Ziv-Welch).

${ }^{24}$ Kontrola bieżąca wykonywanych skanów jest obowiązkowa, zgodnie z $\$ 14$, ust. 3, Zarządzenia $\mathrm{nr} 14$. 
wykonane skany wymagają obróbki w postaci prostowania, kadrowania lub łączenia skanów, skanerzysta wykonuje je osobiście, a w sytuacji bardziej skomplikowanych graficznie czynności udostępnia skany osobie posiadającej odpowiednie oprogramowanie i kompetencje do ich wykonania. Zeskanowane jednostki gromadzone są na regałach w pracowni digitalizacji i podlegają nadzorowi ze strony koordynatora procesu digitalizacji. Odpowiada on za ich skompletowanie, segregację (w przypadku digitalizacji kilku zespołów lub serii jednocześnie), uporządkowanie według kolejności sygnatur oraz zwrot do magazynu po wykonaniu kopii cyfrowych z całości określonej partii archiwaliów.

Katalogi ze skanami, przechowywane czasowo na dyskach twardych komputerów w pracowni digitalizacji, przenoszone są po upływie określonego czasu na macierz dyskową. Odpowiedzialność za nie przejmuje administrator systemu informatycznego, który dokonuje ich uporządkowania w strukturze katalogów, określonej w Zarządzeniu $\mathrm{nr} 14^{25}$. Zgodnie $\mathrm{z}$ nimi administrator nadaje także nazwy poszczególnym skanom, do czego wykorzystuje program umożliwiający masową, automatyczną zmianę tychże nazw ${ }^{26}$. Po zakończeniu ww. czynności tworzy on $\mathrm{z}$ kopii zabezpieczających skompresowane kopie użytkowe $\mathrm{w}$ formacie jpg, przeznaczone do wykonania kontroli poprawności digitalizacji wybranej partii materiałów archiwalnych oraz udostępnia je kontrolerom.

W Archiwum Państwowym w Lublinie kontrolą jakości skanów zajmują się pracownicy czytelni. Kontrola ta ma charakter szczegółowy i obejmuje całość zdigitalizowanych jednostek, bez względu na ich rodzaj czy liczbę skanów ${ }^{27}$. Obejmuje ona techniczne i merytoryczne cechy odwzorowania cyfrowego jednostki, którymi są:

a) techniczne:

- równomierność oświetlenia na skanach;

- widoczność informacji (zwłaszcza przy kalkach, przebitkach, wyblakłych tekstach);

${ }^{25}$ Zarządzenie nr 14, \$13, ust. 1.

${ }^{26}$ Tamże, ust. 1-2. Zadaniem struktury katalogów jest odzwierciedlenie podstawowych danych o lokalizacji danej jednostki w zasobie archiwum. Kolejnymi, hierarchicznymi elementami tej struktury są: numer archiwum/ numer zespołu/c. d. numeru zespołu/ numer serii/ sygnatura jednostki archiwalnej. Nazwa plików cyfrowych składa się z tych samych elementów, co struktura katalogów, z dodatkiem licznika skanów.

${ }^{27}$ Tamże, $\$ 14$, ust. 5, pkt 2 wskazuje na możliwość kontroli losowej w przypadku np. digitalizacji masowej, jednakże nie jest ona stosowana w praktyce lubelskiego Archiwum. 
- estetyka wykonania (obwódka wokół skanów, brak przekrzywień kart, brak wystających kart, widoczność paginacji);

b) merytoryczne:

- poprawność paginacji/foliacji;

- zeskanowanie wszystkich stron/kart (bez powtórzeń stron na skanach);

- kompletność zachowania informacji (czy tekst nie jest zniekształcony, niewidoczny, zasłonięty przez zagięcia lub przycięty ${ }^{28}$.

Zaznaczyć należy, iż osoba kontrolująca nie sprawdza stopnia odwzorowania barw na skanach, ponieważ czynność ta realizowana jest podczas kontroli bieżącej, wykonywanej przez operatora skanera. W przypadku, gdy skany budzą wątpliwości co do jakości i kompletności odwzorowania, kontroler sprawdza zapisy w bazie Digitalizacja dotyczące stanu fizycznego kontrolowanej jednostki w celu określenia, czy wady danych skanów lub informacji na nich zawartych (np. niewidoczny tekst lub błąd w paginacji) wynikają z cech fizycznych jednostki uniemożliwiających pełne odwzorowanie, czy też powstały na skutek błędu skanerzysty. Jeżeli wady wynikają $\mathrm{z}$ błędnego zeskanowania, kontroler opisuje je w bazie (moduł Kontrola skanów) z podaniem stron/kart oraz, jeśli są wymagane, numerów skanów. Wprowadza także dane dotyczące osoby kontrolującej oraz datę wykonania kontroli. Następnie wybiera z menu kontroli opcję Przygotowujący, Skanerzysta lub Administrator w celu określenia osoby/osób odpowiedzialnych za wykonanie wskazanych poprawek. Informacje o poprawkach znajdują się w modułach Przygotowanie jednostek (opcja Poprawki przygotowanie) oraz Skanerzysta (opcja Poprawki skanowanie) i są dostępne dla wszystkich osób pełniących wskazane funkcje.

Wykonywanie poprawek odbywa się z reguły masowo i realizowane jest podczas przygotowywania określonej partii kopii cyfrowych do przekazania do Narodowego Archiwum Cyfrowego w Warszawie celem zabezpieczenia w Centralnym Repozytorium Cyfrowym. Administrator systemu informatycznego, odpowiedzialny za organizację przekazania kopii cyfrowych materiałów archiwalnych do NAC, informuje koordynatora procesu digitalizacji o konieczności wykonania poprawek skontrolowanej partii skanów oraz określa termin realizacji. Do zadań koordynatora, związanych z wykonaniem poprawek, należy zamówienie jednostek archiwalnych, przekazanie osobom przygotowującym tych jednostek, które zostały

${ }^{28}$ Tamże, ust. 1 podaje wykaz cech odwzorowania cyfrowego, jakie podlegają ocenie ze strony kontrolera. 
błędnie spaginowane, bieżąca kontrola nad realizacją poprawek przez operatorów skanerów oraz zwrot jednostek do magazynu po wykonaniu kompletu poprawek.

Osoby przygotowujące, po korekcie błędnej paginacji, przekazują jednostki do pracowni digitalizacji oraz dokonują w bazie zmiany statusu poprawki z Przygotowujący na Skanerzysta. Po wykonaniu skanów tej części jednostki, która posiadała błędną paginację, operator skanera zmienia status poprawki na Administrator. Wykonane w ramach poprawek skany są następnie przenoszone do pierwotnego folderu z kopiami cyfrowymi i zastępują błędne. Ostatnią czynnością na etapie poprawek jest ponowne nadanie nazw tym kopiom cyfrowym, których numeracja została zaburzona, oraz zmiana statusu na Poprawki wykonane. Do tak skontrolowanych, poprawionych i umieszczonych w odpowiedniej strukturze katalogów z kopiami cyfrowymi dołącza się obligatoryjnie metryczkę w wersji cyfrowej $^{29}$. Ma ona postać wygenerowanego z bazy Digitalizacja pliku w formacie tif, zawierającego odpowiednie metadane.

Finalnym etapem w procesie digitalizacji jest zabezpieczenie cyfrowych kopii wzorcowych materiałów archiwalnych na macierzy dyskowej lubelskiego Archiwum oraz przygotowanie ich do zabezpieczenia we wspomnianym wyżej Centralnym Repozytorium Cyfrowym NAC. Określona partia skanów wzorcowych zostaje skopiowana na dyski przenośne, do których dołącza się pismo zawierające wykaz zespołów i sygnatur zdigitalizowanych jednostek archiwalnych. Lubelskie Archiwum przechowuje u siebie kopie wzorcowe do czasu uzyskania z NAC informacji o zabezpieczeniu ich w CRC. Gdy to nastąpi, kopie wzorcowe w Archiwum zostają usunięte i pozostawione jedynie kopie użytkowe w formacie jpg ${ }^{30}$, które udostępnia się użytkownikom w czytelni, jak również umożliwia korzystanie $\mathrm{z}$ nich archiwistom $\mathrm{w}$ ramach ich obowiązków służbowych. Udostępnianie skanów użytkownikom czytelni lubelskiego Archiwum odbywa się przez kopiowanie tychże skanów na dyski twarde komputerów oraz ich usunięcie po zakończeniu korzystania z nich. Nadzór nad udostępnianiem zamówionych skanów należy do administratora systemu informatycznego oraz do pracowników czytelni.

Opisywany wyżej proces digitalizacji lubelskie Archiwum stosuje także w przypadku jednostek archiwalnych, które wprawdzie nie były uwzględniane w planie rocznym digitalizacji, jednakże ich zabezpieczenie podyktowane jest nagłą koniecznością lub względami ekonomii pracy. W pierwszym przypadku są to np. jednostki, które zostały wycofane z planu digitalizacji ze względów konserwatorskich i wróciły

\footnotetext{
${ }^{29}$ Tamże, $\$ 13$, ust. 3, pkt 1. Wzór metryczki określa Załącznik nr 7 do Zarządzenia nr 14.

${ }^{30}$ Kopie te zapisane są w identycznej strukturze katalogów jak dla kopii wzorcowych.
} 
z konserwacji po pewnym czasie. Poddaje się je wtedy digitalizacji bez względu na plan, szczególnie jeśli ich zeskanowanie pozwala na dokończenie digitalizacji danego zespołu archiwalnego. W drugim przypadku, związanym z ekonomią, poddaje się digitalizacji zabezpieczającej te jednostki, które zostały zamówione przez użytkowników czytelni do wykonania z nich kopii cyfrowych (tzw. digitalizacja bieżąca). Istotnym warunkiem jest tutaj wymóg, aby liczba stron, z których użytkownik chce otrzymać kopie cyfrowe, wynosiła minimum 50\% wszystkich stron danej jednostki. Przechodzą one przez przyspieszony proces digitalizacji (z racji terminu wykonania kopii użytkowych dla użytkownika), co oznacza, że po przygotowaniu i opisaniu są one natychmiast skanowane, strukturyzowane (nazewnictwo katalogów i plików), kontrolowane oraz zabezpieczane. Następnie z kopii zabezpieczających wykonuje się kopie użytkowe, z których wskazane partie przekazuje się użytkownikowi zgodnie z jego zamówieniem. Warto także wspomnieć, iż niewielkie jednostki (15-20 stron) mogą być digitalizowane w całości z zachowaniem proporcji nawet 30-40\%, jeśli nie wymagają dodatkowych czynności związanych z przygotowaniem i opisem, a różnica czasu w zeskanowaniu części i całości jest znikoma. Powyższe przypadki występują rzadko i praktycznie nie wpływają na realizację planu digitalizacji, jako że wykonane kopie zabezpieczające są do tego planu zaliczane.

Narodowe Archiwum Cyfrowe odpowiedzialne jest za udostępnienie skanów zdigitalizowanych archiwaliów na portalu szukajwarchiwach.pl. Zamieszcza na nim kopie użytkowe $\mathrm{w}$ formacie jpg o określonych parametrach jakościowych, które wykonywane są w NAC z przesłanych do niego kopii wzorcowych. W drodze porozumienia między informatykami Narodowego Archiwum Cyfrowego i Archiwum Państwowego w Lublinie skany przeznaczone do zamieszczenia na ww. portalu są przygotowywane w lubelskim Archiwum i przesyłane za pomocą protokołu komunikacyjnego FTP (File Transfer Protocol) do NAC ${ }^{31}$.

Przedstawiony proces digitalizacji w lubelskim Archiwum odbywa się także w jego oddziałach zamiejscowych. Proces ten dostosowany jest do ich możliwości kadrowych i organizacyjnych, przy zachowaniu tych samych wymagań odnośnie do kompetencji osób pełniących poszczególne funkcje. Oddziały posiadają także dedykowane wersje bazy Digitalizacja, znajdujące się na serwerze lubelskiego Archiwum i zarządzane przez administratora systemu informatycznego. Do jego kompetencji należy zarządzanie kopiami cyfrowymi wykonanymi w oddziałach

${ }^{31}$ Procedura przekazywania kopii cyfrowych do Centralnego Repozytorium Cyfrowego Archiwów Państwowych (CRC AP) stanowi Załącznik nr 11 do Zarządzenia nr 14. 
zamiejscowych (realizowane przez dostęp zdalny bądź bezpośrednio w ich siedzibach), przenoszenie tychże kopii na macierz dyskową w Centrali oraz przygotowanie ich do zabezpieczenia w CRC.

Jak już wspomniano przy opisie rysu historycznego, stosowany aktualnie w Archiwum Państwowym w Lublinie proces digitalizacji materiałów archiwalnych jest wynikiem wieloletniego doświadczenia jego kadry i profesjonalnego wyposażenia pracowni digitalizacji. W tym miejscu należy wskazać również na chęć korzystania $\mathrm{z}$ dobrych praktyk digitalizacji w innych podmiotach oraz na otwartość Archiwum na ciągły rozwój i wymagania świata cyfrowego w modyfikacji procesu digitalizacji. Nie obyło się bez trudności, zarówno od strony organizacyjnej, jak i sprzętowej. Nowe obowiązki, konieczność stosowania nowych narzędzi informatycznych, mierzenie się z ograniczeniami i usterkami eksploatowanych skanerów, niezgodność między sposobem opracowania jednostek archiwalnych a ich wiernym odwzorowaniem cyfrowym czy dynamiczne koordynowanie czynności wielu osób uczestniczących w procesie digitalizacji przedstawiały niemałe wyzwania. W większości zostały one rozwiązane, choć nie zniknęły całkowicie, zwłaszcza w kwestiach wspomnianych konfliktów opracowania jednostek i wierności ich odwzorowań cyfrowych. Jest to jednak problem złożony i niełatwy do rozwiązania, zwłaszcza że digitalizacja materiałów archiwalnych w działalności archiwów państwowych w Polsce jest dość młodą dziedziną i wiele kwestii czeka jeszcze na swoje rozstrzygnięcia.

\section{Wybrane problemy digitalizacji}

Piętnaście lat działalności Archiwum Państwowego w Lublinie na polu digitalizacji materiałów archiwalnych zaowocowało dużym doświadczeniem w sprawach sprzętowej, kadrowej, proceduralnej oraz merytorycznej organizacji procesu tworzenia kopii cyfrowych archiwaliów. Nie obyło się jednak bez pewnych trudności i problemów, które wymagały kompleksowego rozwiązania. Znaczna część tych trudności miała ogólny charakter i należy założyć, że podobne kwestie występują w wielu instytucjach (nie tylko w archiwach) zajmujących się digitalizacją różnych obiektów. Pozostałe były bardziej specyficzne i wynikały głównie z możliwości organizacyjnych lubelskiego Archiwum oraz postaci niektórych jego zbiorów poddanych skanowaniu. Pojawiły się także pytania i wątpliwości o charakterze merytorycznym, dotyczące zwłaszcza pogodzenia kancelaryjnego układu akt w poszczególnych jednostkach i zespołach archiwalnych z wymogami 
i realiami digitalizacji. Warto podkreślić, iż podjęcie starań w kierunku rozwiązania wszystkich trudności i wątpliwości związanych z digitalizacją archiwaliów wynikało z konieczności tworzenia ich wiernych jakościowo, opisowo i relacyjnie odwzorowan cyfrowych $\mathrm{w}$ postaci skanów ${ }^{32}$. Nie zostały one jeszcze w pełni rozwiązane, co podyktowane jest $\mathrm{z}$ jednej strony ogromną różnorodnością poddawanych skanowaniu jednostek aktowych, a $z$ drugiej nie do końca (zdaniem autorów niniejszego tekstu) jednolitymi wymaganiami co do wspomnianych jakości, opisu i relacyjności kopii cyfrowych z różnych rodzajów materiałów archiwalnych. Odpowiedź na zasadnicze pytanie: czym jest wierne odwzorowanie cyfrowe jednostki archiwalnej? tylko z pozoru jest prosta, a stwierdzenie, że stoi ono u podstaw całej problematyki digitalizacji archiwaliów, nie tylko w lubelskim Archiwum, nie wydaje się przesadzone. Należy w tym miejscu zaznaczyć, że próba teoretycznej odpowiedzi na wyżej postawione pytanie kształtowała się i rozwijała w Archiwum wraz z napotykanymi trudnościami, głównie natury merytorycznej, podczas skanowania archiwaliów o skomplikowanym układzie akt. Nie można zatem opisywać trudności, jakie lubelskie Archiwum napotkało w swej działalności digitalizacyjnej, oraz prób odpowiedzi na pytanie o definicję wiernego odwzorowania cyfrowego jednostki archiwalnej w sposób hierarchiczny i rozłączny. Właściwsze byłoby ujęcie równoległe, w którym opis elementów odwzorowania cyfrowego będzie się przenikał ze wskazaniem zasadniczych trudności w digitalizacji pewnych rodzajów archiwaliów z zasobu Archiwum Państwowego w Lublinie oraz zaprezentowaniem zastosowanych rozwiązań.

Wierne odwzorowanie cyfrowe jednostki archiwalnej zawiera trzy elementy, o których wspomniano wyżej, a mianowicie element jakości (odwzorowanie graficzne), opisu (metadane i uwagi dotyczące układu akt) oraz relacji (ukazanie na skanach wzajemnych powiązań kart i stron dokumentów w jednostce aktowej). Najłatwiej jest określić wymagania dotyczące jakości graficznej kopii cyfrowych. Ustalenie wartości rozdzielczości wymaganej do zabezpieczenia na skanie najmniejszych nawet detali graficznych dokumentu nie nastręcza problemów, a jedyną barierą są w tym przypadku możliwości sprzętowe skanera. Jeszcze mniej trudności stwarza określenie przestrzeni barwnej ${ }^{33}$ oraz głębi bitowej dla

\footnotetext{
${ }^{32}$ Wskazanie w tym miejscu na postać skanu ma na celu odróżnienie go od odwzorowania w postaci fotografii cyfrowej, która nie zapewnia takiej samej jakości i wierności co skan. Archiwum Państwowe w Lublinie nie wykonuje fotografii cyfrowych z materiałów archiwalnych poza wyjątkami w postaci obiektów trójwymiarowych, jak np. tłoki pieczętne.

${ }^{33}$ Zgodnie z Załącznikiem $\mathrm{nr} 1$ do Zarządzenia $\mathrm{nr} 14$ digitalizację należy wykonywać do przestrzeni barwnej Adobe RGB 1998.
} 
poszczególnych postaci materiałów archiwalnych (24-bitowy kolor dla materiałów wielobarwnych, 16-bitowa skala odcieni szarości dla fotografii czarno-białych, 48-bitowy kolor dla fotografii kolorowych, sepii, cyjanotypii i odbitek aluminiowych) oraz format zapisywanych skanów (TIFF dla kopii zabezpieczających, JPG z określoną kompresją dla kopii użytkowych). Element jakości zawiera w sobie także kompletność informacji graficznej na skanie, co oznacza, że cały dokument zostaje odwzorowany w obrębie jednego skanu. W przypadku obiektów wielkoformatowych, niemieszczących się w obszarze roboczym skanera, wiąże się to dodatkowo z koniecznością łączenia skanów poszczególnych fragmentów obiektu w jeden za pomocą programu graficznego. To jedna z pierwszych trudności, na które napotkało lubelskie Archiwum w swej praktyce digitalizacyjnej. Łączenie skanów jest czynnością czasochłonną i wymagającą dużej precyzji, przez co istotnie wpływa na liczbę wykonanych skanów. Trudność ta miała bardziej charakter organizacyjny niż techniczny, ponieważ wpływała na dokładne określenie, ile skanów Archiwum jest w stanie wykonać w danym czasie. Należy zaznaczyć, że dotyczyło to jednostek aktowych, w których znajdowały się takie obiekty, nie zaś zespołów złożonych $\mathrm{z}$ takich obiektów ${ }^{34}$. W przypadku map i planów o formacie powyżej 2xAo Archiwum zazwyczaj pomija etap łączenia skanów w jeden, co spowodowane jest wielkością pliku wyjściowego. Obok szczegółowości i kompletności element jakości odwzorowania cyfrowego posiada również cechę czytelności informacji. Przeważająca część materiałów archiwalnych w postaci papierowej ma dobrą czytelność tekstu i elementów graficznych, $\mathrm{z}$ wyjątkiem tych, w których zastosowane materiały piśmiennicze spowodowały wyblaknięcie tekstu i zniekształcenie barw. Często jednak występują archiwalia tworzone na kalkach technicznych bądź na papierze przebitkowym, co powoduje trudności w odwzorowaniu na skanach tego rodzaju dokumentacji. Źródłem tej trudności jest zastosowanie w skanerach czarnego tła w obszarze roboczym, przez co ma ono wpływ na oddanie kontrastu pomiędzy kolorem dokumentu a zapisaną na nim informacją tekstową i graficzną. Im mniejsza gramatura papieru, tym na skanach wychodzi on ciemniejszy (większa przenikalność czarnego tła obszaru roboczego skanera), a przez to zmniejsza się czytelność samego dokumentu. Rozwiązaniem tego problemu, który nie dotyczy tylko Archiwum Państwowego w Lublinie, jest stosowanie jako tła podkładek w postaci białych arkuszy papieru. Dzięki temu zachowana zostaje czytelność informacji, kosztem jednak wierności odwzorowania samego nośnika, który na skanie wydaje się biały,

${ }^{34}$ Np. 35/22 Akta miasta Lublina, seria 1, Dokumenty miasta Lublina; 35/632 Zbiór afiszów i druków ulotnych. 
choć w rzeczywistości jest przezroczysty. Niemniej pewną informację o tym, że dany dokument jest $\mathrm{w}$ oryginale przezroczysty, stanowi widoczność białej ramki na skanie. Lubelskie Archiwum stosuje także czarne podkładki w trakcie skanowania, gdy układ akt w jednostce archiwalnej oraz jej postać (zwłaszcza poszyt różnoformatowy) powodują wystawanie jednych dokumentów zza drugich. Zastosowanie czarnego tła pozwala na oddzielenie ich od siebie i uniknięcie zlewania się treści $\mathrm{z}$ kilku stron na jednym skanie ${ }^{35}$. Niestety niesie to ze sobą znaczne wydłużenie czasu potrzebnego na zdigitalizowanie jednostki archiwalnej. Fakt ten stoi u podstaw decyzji o rozszywaniu w lubelskim Archiwum tych jednostek archiwalnych, które składają się z dokumentów różnoformatowych, i uformowanie ich w postać poszytu, co nie było czynnością przewidzianą przez aktotwórcę ${ }^{36}$.

Trudniejsze do zdefiniowania są wymagania opisu zdigitalizowanej jednostki archiwalnej związane z jego poziomem i szczegółowością. Nie obejmuje to metadanych, które jako jednostkowe informacje można łatwo zdefiniować i zapisaćc ${ }^{37}$. Wspomniany poziom opisu obecnie zatrzymuje się na poziomie jednostki archiwalnej $^{38}$, a nie na pojedynczym dokumencie należącym do tej jednostki. Bez podstawowych informacji na temat dokumentów zawartych w jednostce użytkownik korzystający z jej kopii cyfrowej ma utrudnione zadanie dotarcia do interesujących go treści, a sam tytuł jednostki nie zawsze zawiera wystarczająco dużo informacji pozwalających na choćby przybliżone określenie jej zawartości. Z drugiej jednak strony realne ograniczenia czasowe związane z opracowywaniem archiwaliów uniemożliwiają takie uszczegółowienie opisu, które zawierałoby wszystkie ważne informacje zawarte na dokumencie. Złotym środkiem wydaje się opatrzenie każdego dokumentu w jednostce archiwalnej przygotowywanej do digitalizacji metadanymi o jego postaci i formie. Dla przykładu, jako postać dokumentu można podać: pismo, fotografia, tabela (wykaz), plan, mapa, rysunek etc., jako formę natomiast: podanie, wniosek, formularz, decyzja, skarga, wyrok etc., w zależności od tych spotykanych w archiwaliach przeznaczonych do digitalizacji. Pozwoliłoby

${ }^{35}$ Zasada kompletności zachowania informacji na skanie dotyczy także nieprzenikania informacji z innych dokumentów.

${ }^{36}$ Księgi oraz jednostki oryginalnie szyte nie podlegają rozszywaniu, bez względu na stopień zróżnicowania formatów występujących w nich dokumentów.

${ }^{37}$ Załącznik nr 5 do Zarządzenia nr 14 zawiera w części B zasady dodawania metadanych do tworzonych kopii cyfrowych, jak również wykaz tych metadanych dla kopii zabezpieczających i użytkowych.

${ }^{38}$ Nie dotyczy to rzecz jasna jednostek archiwalnych złożonych wyłącznie z fotografii (specyficzne elementy opisu, jak np. temat) lub zawierających jeden dokument (plan, mapa, dokument wielkoformatowy, plakat, afisz). 
to nie tylko na dokładniejsze rozeznanie zawartości jednostek archiwalnych, ale także na utworzenie słów kluczowych (tagów), tak bardzo przydatnych podczas wyszukiwania informacji. Obecnie takie rozwiązanie w szerokiej praktyce digitalizacyjnej archiwów państwowych, a więc i w lubelskim Archiwum, nie funkcjonuje $^{39}$. Związane jest to $\mathrm{z}$ tym, iz przygotowaniem jednostek do digitalizacji zajmują się głównie pracownicy archiwum, którzy z racji pełnionych funkcji nie mogą poświęcić znacznej części czasu pracy na tak szczegółowy opis tychże jednostek.

Najtrudniejsze, gdyż wynikające z ogromnej różnorodności i unikatowości archiwaliów oraz niejednorodnego układu akt wewnątrz jednostek archiwalnych, jest określenie jednolitych wymagań dotyczących elementu relacji odwzorowania cyfrowego dokumentów w tychże jednostkach, zwłaszcza kolejności treści w dokumentach. Relacje między poszczególnymi kartami i stronami dokumentów to informacje, których oddanie na skanach stanowi pewne wyzwanie ${ }^{40}$. Fizyczna postać archiwaliów pozwala na dostrzeżenie relacji, jak chociażby tej, że jeden dokument składa się z czterech zapisanych tekstem ciągłym stron (jedna złożona karta lub kilka sklejonych, zszytych), a inny dokument „zawiera w sobie” dodatkowe dokumenty, co wynika z układu akt. Na skanach natomiast, z racji ich dwuwymiarowości, trudno nieraz dostrzec te elementy, co w szczególności dotyczy wspomnianej ciągłości tekstu na kolejnych stronach dokumentu. Oczywiste jest, że dostrzeżenie relacyjności na kolejnych skanach nie stanowi problemu w przypadku digitalizacji ksiąg lub archiwaliów w postaci luzów czy poszytów, z których każdy dokument jest ułożony odrębnie od pozostałych. Inaczej jest w przypadku tzw. składek dokumentów, w których jeden dokument stanowi swoistą „obwolutę" dla pozostałych. Jeśli ów dokument zapisany jest tylko na pierwszej i drugiej stronie, to kolejny numer paginacji znajdzie się na następnej stronie, nie zaburzając ciągłości informacji, jaką zawiera cały dokument. Jednak w przypadku, gdy dokument, będący wspomnianą obwolutą dla pozostałych, zapisany jest na trzeciej i czwartej stronie w sposób ciągły (kontynuacja stron pierwszej i drugiej), strony te zostaną zeskanowane dopiero po wszystkich dokumentach znajdujących się wewnątrz tej składki. Wynika to ze wspomnianego układu akt, wymogu jego zachowania (archiwalna zasada nienaruszalności kancelaryjnego układu akt) oraz

\footnotetext{
${ }^{39}$ Jako wyjątek można podać opracowanie i digitalizację fotografii z zasobu NAC, które umieszczane są na stronie www.audiovis.nac.gov.pl.

${ }^{40}$ Rozporządzenie Ministra Spraw Wewnętrznych i Administracji z 30 X 2006 r. w sprawie niezbędnych elementów struktury dokumentów elektronicznych wskazuje $\mathrm{w} \$ 2.1$. na znaczenie takich metadanych dokumentu elektronicznego, które ułatwiają jego zrozumienie.
} 
paginowania kolejnych stron dokumentów w jednostce archiwalnej ${ }^{41}$. Niestety, taki sposób zeskanowania składek dokumentów nie pozwala na oddanie relacyjności poszczególnych kart i stron na kolejno następujących po sobie skanach, ponieważ ww. zasady trudno jest pogodzić w praktyce skanowania. Konieczny zatem staje się pewien kompromis w odwzorowaniu relacyjności kolejnych kart i stron omawianych dokumentów i ich układu w jednostce. Kompromis ten jest źródłem wspomnianych trudności w ustaleniu jednolitych wymagań dotyczących elementu relacji odwzorowania cyfrowego dokumentów, ponieważ w zależności od rodzaju archiwaliów różne elementy relacji należy przedłożyć ponad inne. Pewnym ogólnym rozwiązaniem wydaje się praktyka skanowania wewnętrznej strony dokumentu wraz ze stroną kolejną (mimo jej „oddalenia” w paginacji o kilka lub nawet kilkadziesiąt stron innych dokumentów w składce $)^{42}$, co daje informację o tym, jaka treść znajduje się na tej kolejnej stronie. Musi to jednak iść w parze z odpowiednim opisem takiego dokumentu - „obwoluty” - w ewidencji kopii cyfrowych przez zastosowanie opisu, przykładowo: „Strony 1, 2, 49, 50 stanowią jeden dokument”. Brak takiego opisu nie pozwala na uchwycenie owej ciągłości informacji, a przez to obniża wartość odwzorowania cyfrowego jednostki archiwalnej, gdyż nie dostarcza istotnych informacji dotyczących omawianych dokumentów i ich układu. Należy jednak zaznaczyć, że również w przypadku ww. opisu główną przeszkodą w jego stosowaniu są ograniczenia czasowe związane z przygotowywaniem materiałów archiwalnych do digitalizacji ${ }^{43}$.

Innego rodzaju zagadnieniem $\mathrm{w}$ zachowywaniu elementu relacyjności odwzorowania cyfrowego jest postępowanie z pustymi (niezapisanymi) stronami dokumentów. Zarządzenie nr 14 pośrednio postuluje ich opuszczanie $\mathrm{w}$ trakcie skanowania jednostki ${ }^{44}$, co podyktowane jest faktem oszczędności

${ }^{41}$ W zasobie Archiwum Państwowego w Lublinie znajdują się np. akta tzw. kancelarii rosyjskiej, które charakteryzują się omawianym układem akt w postaci składek dokumentów. Jako przykład zespołów zawierających taki układ akt można wymienić: 35/22 Akta miasta Lublina, Urząd Municypalny i Magistrat miasta Lublina 1809-1874 lub 35/115 Komisja Województwa Lubelskiego i Rząd Gubernialny Lubelski.

${ }^{42}$ Praktyka stosowana w lubelskim Archiwum.

${ }^{43}$ Zarządzenie nr $14 \mathrm{w} \$ 8$, ust. 1, pkt 5, ppkt d, wskazuje, że „w metryczce w rubryce Uwagi sygnalizuje się występujące w poszytach z XIX w. (akta kancelarii rosyjskiej) zaburzenia kolejności pism w obrębie składek wynikające z wadliwego zszycia, utrzymując jednakże kolejność numerowania następujących po sobie stron”. W zapisie tym nie określa się szczegółowości opisu, a użycie słowa „sygnalizować” zdaje się wskazywać na krótką tylko informację o występowaniu zaburzenia.

${ }^{44}$ Tamże, ppkt e. 
miejsca, jako że puste strony nieraz stanowią prawie połowę wszystkich kart $\mathrm{w}$ jednostce. $\mathrm{Z}$ drugiej strony istotny jest fakt, że z fizycznego punktu widzenia puste strony dokumentów wchodzą w skład opracowanej jednostki (nie zostały wybrakowane), co może przemawiać za opcją skanowania również pustych stron $\mathrm{w}$ ramach pełnego odwzorowania nie tylko informacji tekstowych i graficznych, ale także samego stanu fizycznego jednostki. Ostatecznie wydaje się jednak, że kwestie ekonomii miejsca zajmowanego przez kopie cyfrowe, a co za tym idzie, pomijanie w skanowaniu stron pustych, są mocniejszym argumentem niż odwzorowanie fizycznej strony jednostki archiwalnej, a dodatkowo zasada „brak wiadomości to także wiadomość" nie ma w przypadku stron pustych merytorycznego zastosowania. Innego postępowania wymagają formularze oraz wszelkie pisma posiadające formę druku do wypełnienia. Dokumenty w takiej postaci skanowane są, w praktyce lubelskiego Archiwum, w całości, bez względu na to, ile stron danego formularza jest wypełnionych. Wynika to z przytoczonej już zasady o braku wiadomości, która w przypadku formularzy ma pełne zastosowanie. Wyjątkiem są księgi zawierające szereg identycznych formularzy, z których część jest niezapisana - traktuje się je jako strony puste i pomija podczas skanowania. Kolejnym zagadnieniem, trudnym do jednoznacznego rozwiązania, jest częste występowanie w jednostkach archiwalnych wtórnie wykorzystanych nośników papierowych, których elementy graficzne i tekstowe są niezwiązane merytorycznie $\mathrm{z}$ treścią dokumentów wchodzących w skład tych jednostek. Trudność wynika tutaj, podobnie jak w przypadku stron pustych, z konfliktu pomiędzy ekonomią miejsca a pełnym odwzorowaniem strony fizycznej jednostki oraz z wielkiej różnorodności treściowej wtórnie wykorzystanych nośników. Kluczem do rozwiązania jest określenie wartości treści zawartych po zapisanej pierwotnie stronie wtórnie wykorzystanej karty papieru, co niestety wymaga czasu i namysłu nad każdym dokumentem osobno. W związku z tym w lubelskim Archiwum przyjęto ogólną zasadę, aby wszelkie wątpliwości tego typu rozwiązywać „na korzyść” takich stron, uwzględniając je w paginowaniu i skanowaniu. Wprawdzie powoduje to powstanie w kopii cyfrowej jednostki swoistego szumu informacyjnego, gdzie treści merytoryczne mieszają się $\mathrm{w}$ ciągu skanów $\mathrm{z}$ treściami niemerytorycznymi ${ }^{45}$, ale jednak możliwość wystąpienia treści ciekawej, choć niemerytorycznej z punktu widzenia zawartości danej jednostki, przemawia za ich zabezpieczeniem cyfrowym.

${ }^{45}$ Podkreślić należy, że ów swoisty szum informacyjny dotyczy jedynie kopii cyfrowej, której użytkowanie ma nieco inny charakter niż korzystanie z oryginałów analogowych. 
Dla podsumowania opisanej wyżej ważności zachowania elementu jakości, opisu i relacji w odwzorowaniach cyfrowych jednostek archiwalnych warto przytoczyć artykuł Luciany Duranti o wiarygodności i autentyczności dokumentów ${ }^{46}$. Dokonując nieco szerszej jego interpretacji, można powiedzieć, że kopie cyfrowe materiałów archiwalnych również mają wspomniane wyżej cechy ${ }^{47}$. Kopie cyfrowe archiwaliów zawierają metadane związane $\mathrm{z}$ datą oraz pośrednią identyfikacją operatora skanera (poprzez metadane o sprzęcie, na którym pracuje dana osoba), a proces ich wytwarzania i kontroli przebiega według określonej procedury digitalizacji. Niestety, procedura ta obecnie nie skupia się w dostateczny sposób na elemencie opisu i relacyjności skanów względem siebie (w przypadku omawianych archiwaliów i ich układu), przez co nie zapewnia wystarczającego poziomu wiarygodności informacji na nich zawartych ${ }^{48}$. Jasne jest, że akta kancelarii rosyjskiej $\mathrm{i}$ inne archiwalia $\mathrm{z}$ „problematycznymi” układami akt można wyłączyć z planów digitalizacji, ale takie rozwiązanie, zwłaszcza w przypadku ich dużej wartości historycznej, jest tylko odsunięciem problemu, a nie jego rozwiązaniem.

${ }^{46}$ L. Duranti, Reliability and Authenticity: The Concepts and Their Implications, „Archivaria” T. 39,1995 , s. 5-10.

47 Autentyczność skanów oznacza, że wiernie oddają one graficzną i tekstową stronę dokumentów, które nie zostały w żaden sposób zmodyfikowane: „A record is authentic when it is the document that it claims to be. (...) It (...) warrants that the record does not result from any manipulation, substitution, or falsification occurring after the completion of its procedure of creation, and that it is therefore what it purports to be", L. Duranti, dz. cyt., s. 7-8. Brak jakichkolwiek graficznych modyfikacji w cyfrowej kopii wzorcowej archiwaliów jest jedną z podstawowych zasad skanowania zawartych w Zarządzeniu nr 14 i dzięki temu odpowiada na wymagania autentyczności. Wiarygodność natomiast, z racji wspomnianych ograniczeń czasowych oraz specyfiki układu akt, stanowi dziś dla archiwów państwowych wyzwanie organizacyjne i merytoryczne. Jak zaznacza Duranti, wiarygodność dokumentu, a zatem pośrednio jego kopii cyfrowej, opiera się na jego formie, czyli dacie i uwierzytelnieniu w postaci podpisu, oraz procedurze jego wytworzenia poprzez system jednolitych reguł oraz ich kontrolę: „Reliability is provided to a record by its form and procedure of creation. (...) The two most commonly required elements of form are the date and the sub- or super-scription. (...) The procedure of creation of a record is the body of rules according to which acts or portions of them are recorded. (...) Degree of completeness and degree of control of the procedure of creation are the only two factors that determine the reliability of records", L. Duranti, dz. cyt., s. 6.

${ }^{48}$ Na problem częstego braku odpowiednich standardów digitalizacji, niezbędnych do zapewnienia właściwego poziomu wiarygodności i autentyczności kopii cyfrowych archiwaliów, wskazuje także Anne Thurston: „Too often, the management and quality control framework needed to ensure that the digitised records meet requirements for legal admissibility, reliability, authenticity and long-term preservation have not been developed", A. Thurston, Digitisation and preservation - global opportunities and challenges, „Archeion” T. 113, 2012, s. 6o. [Tłumaczenie dostępne w j. polskim]. 
Powyższa próba odpowiedzi na pytanie: czym jest wierne odwzorowanie cyfrowe jednostki archiwalnej? pokazuje, iż ograniczenia czasowe oraz te wynikające ze specyfiki układu akt w niektórych jednostkach archiwalnych wymuszają stosowanie kompromisów, w wyniku których część informacji nie zostanie na skanach umieszczona. Jest to niezbędny aspekt rozwiązań w procesie digitalizacji i Archiwum Państwowemu w Lublinie takie doświadczenie nie jest obce. Nawet takie rozwiązanie, żeby dla każdej informacji niezamieszczonej na skanie istniał jej ślad w postaci opisu w ewidencji kopii cyfrowych, natrafia na duże przeszkody, a śladowe ilości informacji (np. „zaburzenia kolejności pism w obrębie składek dokumentów wynikające z wadliwego zszycia") są praktycznie bezwartościowe, jeśli nie będą uszczegółowione w takim stopniu, aby użytkownik nie musiał sięgać do oryginalnych materiałów archiwalnych. Zgodnie ze słowami Duranti, „Autentyczne, niewiarygodne dokumenty [tutaj: kopie cyfrowe] są bezużyteczne dla obecnych i przyszłych użytkowników, a to oznacza, że pierwszą rzeczą, jaką musimy zagwarantować, jest wiarygodność dokumentów"49.

Tab. 1. Statystyka wykonanych zabezpieczających kopii cyfrowych

(stan na 31 XII 2016 r.)

\begin{tabular}{|c|c|c|c|c|}
\hline $\begin{array}{l}\text { Rok digi- } \\
\text { talizacji }\end{array}$ & $\begin{array}{l}\text { Pracownia } \\
\text { digitalizacji }\end{array}$ & $\begin{array}{l}\text { Finansowanie digitalizacji } \\
\text { (działalność statutowa, WPR } \\
\text { Kultura+, program NDAP) }\end{array}$ & $\begin{array}{l}\text { Liczba } \\
\text { skanów }\end{array}$ & $\begin{array}{l}\text { Razem } \\
\text { skanów }\end{array}$ \\
\hline 2002 & Centrala & \multicolumn{3}{|c|}{ początki digitalizacji, testowanie pierwszego skanera } \\
\hline 2003 & Centrala & działalność statutowa & 5000 & 5000 \\
\hline 2004 & Centrala & działalność statutowa & 2900 & 2900 \\
\hline 2005 & Centrala & działalność statutowa & 3900 & 3900 \\
\hline 2006 & Centrala & działalność statutowa & 4300 & 4300 \\
\hline 2007 & Centrala & działalność statutowa & 3060 & 3060 \\
\hline 2008 & Centrala & działalność statutowa & 46169 & 46169 \\
\hline 2009 & Centrala & działalność statutowa & 69399 & 69399 \\
\hline 2010 & Centrala & działalność statutowa & 53392 & 53392 \\
\hline \multirow[t]{2}{*}{2011} & \multirow[t]{2}{*}{ Centrala } & działalność statutowa & 143335 & \multirow[b]{2}{*}{293354} \\
\hline & & WPR Kultura+ & 150019 & \\
\hline
\end{tabular}

49 „Authentic, unreliable records are of no use to present and future users, and this means that the primary thing we need to guarantee is the reliability of the records", L. Duranti, dz. cyt., s. 8. 
Michał Zawada, Marek Krzykała

\begin{tabular}{|c|c|c|c|c|}
\hline $\begin{array}{l}\text { Rok digi- } \\
\text { talizacji }\end{array}$ & $\begin{array}{l}\text { Pracownia } \\
\text { digitalizacji }\end{array}$ & $\begin{array}{c}\text { Finansowanie digitalizacji } \\
\text { (działalność statutowa, WPR } \\
\text { Kultura+, program NDAP) }\end{array}$ & $\begin{array}{l}\text { Liczba } \\
\text { skanów }\end{array}$ & $\begin{array}{l}\text { Razem } \\
\text { skanów }\end{array}$ \\
\hline \multirow[t]{4}{*}{2012} & \multirow[t]{2}{*}{ Centrala } & działalność statutowa & 182865 & \multirow[b]{2}{*}{388914} \\
\hline & & WPR Kultura+ & 206049 & \\
\hline & \multirow[t]{2}{*}{ o. z. Radzyń Podlaski } & działalność statutowa & 1270 & \multirow[b]{2}{*}{1270} \\
\hline & & WPR Kultura+ & 0 & \\
\hline \multirow[t]{6}{*}{2013} & \multirow[t]{3}{*}{ Centrala } & działalność statutowa & 247698 & \multirow[b]{3}{*}{570277} \\
\hline & & WPR Kultura+ & 213364 & \\
\hline & & Projekt NDAP & 109215 & \\
\hline & \multirow[t]{3}{*}{ o. z. Radzyń Podlaski } & działalność statutowa & 5246 & \multirow[b]{3}{*}{25506} \\
\hline & & WPR Kultura+ & 20260 & \\
\hline & & Projekt NDAP & 0 & \\
\hline \multirow[t]{6}{*}{2014} & \multirow[t]{3}{*}{ Centrala } & działalność statutowa & 215585 & \multirow[b]{3}{*}{562675} \\
\hline & & WPR Kultura+ & 235552 & \\
\hline & & Projekt NDAP & 111538 & \\
\hline & \multirow{3}{*}{ o. z. Radzyń Podlaski } & działalność statutowa & 12741 & \multirow[b]{3}{*}{43790} \\
\hline & & WPR Kultura+ & 31049 & \\
\hline & & Projekt NDAP & 0 & \\
\hline \multirow[t]{6}{*}{2014} & \multirow[t]{3}{*}{ o. z. Kraśnik } & działalność statutowa & 20202 & \multirow[b]{3}{*}{45774} \\
\hline & & WPR Kultura+ & 25572 & \\
\hline & & Projekt NDAP & 0 & \\
\hline & \multirow[t]{3}{*}{ o. z. Chełm } & działalność statutowa & 15134 & \multirow[b]{3}{*}{26085} \\
\hline & & WPR Kultura+ & 10951 & \\
\hline & & Projekt NDAP & 0 & \\
\hline
\end{tabular}


Piętnaście lat digitalizacji w Archiwum Państwowym w Lublinie

\begin{tabular}{|c|c|c|c|c|}
\hline $\begin{array}{l}\text { Rok digi- } \\
\text { talizacji }\end{array}$ & $\begin{array}{l}\text { Pracownia } \\
\text { digitalizacji }\end{array}$ & $\begin{array}{l}\text { Finansowanie digitalizacji } \\
\text { (działalność statutowa, WPR } \\
\text { Kultura+, program NDAP) }\end{array}$ & $\begin{array}{l}\text { Liczba } \\
\text { skanów }\end{array}$ & $\begin{array}{l}\text { Razem } \\
\text { skanów }\end{array}$ \\
\hline \multirow[t]{12}{*}{2015} & \multirow[t]{3}{*}{ Centrala } & działalność statutowa & 285979 & \multirow[b]{3}{*}{588139} \\
\hline & & WPR Kultura+ & 231316 & \\
\hline & & Projekt NDAP & 70844 & \\
\hline & \multirow[t]{3}{*}{ o. z. Radzyń Podlaski } & działalność statutowa & 20055 & \multirow[b]{3}{*}{47934} \\
\hline & & WPR Kultura+ & 27879 & \\
\hline & & Projekt NDAP & 0 & \\
\hline & \multirow[t]{3}{*}{ o. z. Kraśnik } & działalność statutowa & 23263 & \multirow[b]{3}{*}{58942} \\
\hline & & WPR Kultura+ & 35679 & \\
\hline & & Projekt NDAP & 0 & \\
\hline & \multirow[t]{3}{*}{ o. z. Chełm } & działalność statutowa & 14545 & \multirow[b]{3}{*}{24781} \\
\hline & & WPR Kultura+ & 10236 & \\
\hline & & Projekt NDAP & 0 & \\
\hline \multirow[t]{8}{*}{2016} & \multirow[t]{2}{*}{ Centrala } & działalność statutowa & 219287 & \multirow[b]{2}{*}{343658} \\
\hline & & Projekty NDAP & 124371 & \\
\hline & \multirow[t]{2}{*}{ o. z. Radzyń Podlaski } & działalność statutowa & 20367 & \multirow[b]{2}{*}{20367} \\
\hline & & Projekty NDAP & 0 & \\
\hline & \multirow[t]{2}{*}{ o. z. Kraśnik } & działalność statutowa & 21854 & \multirow[b]{2}{*}{21584} \\
\hline & & Projekty NDAP & 0 & \\
\hline & \multirow[t]{2}{*}{ o. z. Chełm } & działalność statutowa & 10073 & \multirow[b]{2}{*}{10073} \\
\hline & & Projekty NDAP & 0 & \\
\hline \multicolumn{4}{|c|}{ RAZEM SKANÓW } & 3261243 \\
\hline
\end{tabular}

Piętnaście lat digitalizacji materiałów archiwalnych w Archiwum Państwowym w Lublinie to pokaźny i bogaty w doświadczenia okres. Dobre praktyki digitalizacji, sprawnie ukształtowany jej proces i jasny podział kompetencji przenikają się w tym czasie z trudnościami, które Archiwum musiało na tej drodze pokonać. Początkowe ograniczenia sprzętowe i kadrowe, merytoryczne rozterki, jak chociażby te związane ze sposobem paginowania i przygotowania jednostek archiwalnych do digitalizacji, czy nieuniknione awarie skanerów - to wszystko stanowiło dla Archiwum niewątpliwe wyzwania, których rozwiązanie wymagało często przecierania nowych szlaków. Co więcej, trudności i wyzwania w digitalizacji nie znikły 
do dzisiaj, i po 15 latach Archiwum napotyka wciąż nowe. Wykorzystując je jako okazje do nowych rozwiązań i ulepszeń procesu digitalizacji, Archiwum Państwowe w Lublinie z każdym rokiem nabywa coraz większej praktyki w digitalizacji, dzięki czemu może dzielić się z innymi swoją wiedzą i doświadczeniem.

\section{Summary}

\section{Fifteen years of digitization in The State Archive in Lublin}

The State Archive in Lublin is digitizing archival materials since year 2002 and is still one of pioneers among state archives in this matter. The State Archive in Lublin is continuously controlling process of digitization accepted in its organizational structures in attempt to adjust this process to constantly evolving demands of digital world and informative society. Thanks to this fact Archive provides fulfillment to archival mission of persistent preservation of past testimonies and guarantee of common access to them for the purpose of support for development of The State and of informative society. Experience gained by The State Archive in Lublin during 15 years of digitization of its own fonds is a result of clearly specified rules from Chief Directorate and constructive implementation of these by Directorate and employees of Archive responsible for process of digitization. Fulfilling goals of digitization of archives - from determining hardware and personnel needs, through progress of digitization process, to theoretical thoughts on accurate digital representations of records - Archive in Lublin can rightly be proud of its substantial contribution into digital preservation and access to archival fonds.

KEYWORDS: digitization, preservation, access, digital copy, scanner. 